\title{
Daily ozone cycle in the stratosphere: global, regional and seasonal behaviour modelled with the Whole Atmosphere Community Climate Model
}

\author{
A. Schanz, K. Hocke, and N. Kämpfer \\ Institute of Applied Physics, Oeschger Centre for Climate Change Research, University of Bern, Bern, Switzerland \\ Correspondence to: A. Schanz (ansgar.schanz@iap.unibe.ch)
}

Received: 17 December 2013 - Published in Atmos. Chem. Phys. Discuss.: 3 March 2014

Revised: 19 June 2014 - Accepted: 20 June 2014 - Published: 30 July 2014

\begin{abstract}
The Whole Atmosphere Community Climate Model (WACCM) is utilised to study the daily ozone cycle and underlying photochemical and dynamical processes. The analysis is focused on the daily ozone cycle in the middle stratosphere at $5 \mathrm{hPa}$ where satellite-based trend estimates of stratospheric ozone are most biased by diurnal sampling effects and drifting satellite orbits. The simulated ozone cycle shows a minimum after sunrise and a maximum in the late afternoon. Further, a seasonal variation of the daily ozone cycle in the stratosphere was found. Depending on season and latitude, the peak-to-valley difference of the daily ozone cycle varies mostly between 3 and $5 \%$ ( $0.4 \mathrm{ppmv})$ with respect to the midnight ozone volume mixing ratio. The maximal variation of $15 \%(0.8 \mathrm{ppmv})$ is found at the polar circle in summer. The global pattern of the strength of the daily ozone cycle is mainly governed by the solar zenith angle and the sunshine duration. In addition, we find synoptic-scale variations in the strength of the daily ozone cycle. These variations are often anti-correlated to regional temperature anomalies and are due to the temperature dependence of the rate coefficients $k_{2}$ and $k_{3}$ of the Chapman cycle reactions. Further, the $\mathrm{NO}_{\mathrm{x}}$ catalytic cycle counteracts the accumulation of ozone during daytime and leads to an anti-correlation between anomalies in $\mathrm{NO}_{\mathrm{x}}$ and the strength of the daily ozone cycle. Similarly, ozone recombines with atomic oxygen which leads to an anti-correlation between anomalies in ozone abundance and the strength of the daily ozone cycle. At higher latitudes, an increase of the westerly (easterly) wind cause a decrease (increase) in the sunshine duration of an air parcel leading to a weaker (stronger) daily ozone cycle.
\end{abstract}

\section{Introduction}

Despite being a minor constituent, ozone has a major impact on the Earth system. The stratospheric ozone layer absorbs solar radiation at short wavelengths and thus protects the biosphere from harmful ultraviolet radiation. Furthermore, the thermal state of the stratosphere mainly depends on absorption of downwelling ultraviolet and upwelling infrared radiation by ozone molecules. The associated production and destruction processes were described for the first time by the so-called Chapman cycle (Chapman, 1930), based on pureoxygen photochemistry. Later, the investigation of catalytic ozone depletion cycles revealed additional destruction processes of ozone. In particular, odd nitrogen $\left(\mathrm{NO}_{\mathrm{y}}\right)$ and odd chlorine $\left(\mathrm{Cl}_{\mathrm{y}}\right)$ cause catalytic ozone depletion in the stratosphere (Crutzen, 1970; Johnston, 1971; Stolarski and Cicerone, 1974).

In the 1970s, Molina and Rowland (1974) indicated that, based on catalytic ozone depletion, anthropogenic emission of chlorofluorocarbons (CFCs) potentially damages the stratospheric ozone layer globally. Ozone observations in the mid-80s suprisingly showed the existence of the Antarctic ozone hole (Chubachi, 1985; Farman et al., 1985). To avert further depletion of stratospheric ozone, a ban of manmade CFC emissions was negotiated in the Montreal Protocol (Sarma and Bankobeza, 2000).

In fact, present observations indicate a tendency for a slow recovery of the stratospheric ozone layer (Jonsson et al, 2009; Garny et al., 2013; Chehade et al., 2014; Kyrölä et al., 2014; Gebhardt et al., 2014). Projections of chemistryclimate models indicate a return of stratospheric ozone concentrations to their 1980s level in the period between 2040 
and 2050 (Eyring et al., 2007). Recent studies show that unregulated anthropogenic $\mathrm{N}_{2} \mathrm{O}$ emissions are the dominant ozone-depleting emission in the 21st century (Ravishankara et al., 2009). The increasing $\mathrm{N}_{2} \mathrm{O}$ fluxes from the troposphere and $\mathrm{CH}_{4}$ play an increasing role in determining stratospheric ozone and potentially delay the recovery of the ozone layer (Revell et al., 2012; Shindell et al., 1998).

The diurnal variation of stratospheric ozone was simulated with a photochemical box model at northern midlatitudes by Herman (1979). This model depicted a strong decrease of ozone during daytime at $55 \mathrm{~km}$ in the mesosphere $(-25 \%)$ and a weaker variation $( \pm 5 \%)$ at $40 \mathrm{~km}$ in the stratosphere. Pallister and Tuck (1983) modelled the diurnal ozone cycle at $34^{\circ} \mathrm{N}$ with a photochemical box model and confirmed the results of Herman (1979). Furthermore, Fabian et al. (1982) indicated latitudinal and seasonal effects by utilisation of a two-dimensional, zonally averaged model. At that time the model utilised by Fabian et al. (1982) did not couple dynamics and diurnal photochemistry. Observations as rocket-based measurements of day- and night-time ozone (Lean, 1982) and balloon-borne measurements (Aimedieu et al., 1981) seemed to support the simulation results of Fabian et al. (1982); Herman (1979) and Pallister and Tuck (1983). However, quality and sampling of the few measurements were not sufficient to give observational evidence for the small, daily cycle of stratospheric ozone.

Nowadays, there exist more observations of the daily cycle of stratospheric ozone which agree well with the numerical simulation results of the photochemical models. Connor et al. (1994) presented diurnal variation in stratospheric and mesospheric ozone from 9 months of observations of a groundbased microwave radiometer at Oroville, California. Haefele et al. (2008) found a daily ozone cycle in the observations of the Ground-based Millimeter-wave Ozone Spectrometer (GROMOS) which operates at Bern, Switzerland as part of Network for the Detection of Atmospheric Composition Change (NDACC). Later, Studer et al. (2014) derived a monthly climatology of diurnal variation in stratospheric and mesospheric ozone from 17 years of GROMOS observations. Satellite-based observations from SMILES (Superconducting Submillimeter-Wave Limb-Emission Sounder) (Kikuchi et al., 2013), SABER (Sounding of the Atmosphere using Broadband Emission Radiometry) (Russell et al., 1999) and MLS (Microwave Limb Sounder) (Barth et al., 1983) showed the existence of a daily ozone cycle in the stratosphere at tropical and midlatitudes (Huang et al., 2008; Sakazaki et al., 2013). There is also some evidence that these data show good agreement with model data at tropical latitudes (Sakazaki et al., 2013).

Trend studies on the global stratospheric ozone distribution are mainly based on ozone measurements from satellites (e.g. Stolarski and Frith, 2006). After years in operation satellite orbits potentially drift away from their initial orbits, so that the measurements are taken at local times differing by hours from the initial measurements (DeLand et al., 2012).
In this context, diurnal ozone variation and its global pattern should be taken into account for a correction of the satellite ozone data (e.g. Bhartia et al., 2013). The recovery of the stratospheric ozone layer is expected to be approximately $1 \%$ per decade (Garny et al., 2013; Chehade et al., 2014) so that even small diurnal ozone variations can seriously bias the ozone trend estimate. To date, most observations based on satellites with different equator-crossing times are analysed without any consideration of diurnal ozone variations (Bhartia et al., 2013).

Aside from the trend analysis, current research considers ozone as a source of excitation of atmospheric tides which in turn affect the daily ozone cycle (Sakazaki et al., 2013). Further, fundamental research on photochemistry by modelling the diurnal variations of ozone, ozone-depleting substances and other trace gases (Muncaster et al., 2012; Khosravi et al., 2013 ) is investigated as is the derivation of reaction rates (Kuribayashi et al., 2014).

The work presented here provides a first overview of global, seasonal and regional behaviour of the daily ozone cycle in the stratosphere. We look at the dependence of the daily ozone cycle on geographic longitude, which has not been discussed in previous observational or modelling studies. In order to understand and estimate the effects, we perform a three-dimensional high-resolution numerical simulation with the WACCM model. This model includes the physical and chemical processes which are relevant for the daily ozone cycle (e.g. detailed photochemistry, transport, vertical mixing, parametrised gravity wave fluxes). In addition, the model provides a realistic composition and circulation of the middle atmosphere.

In Sect. 2 the WACCM model and its setup for simulating the daily ozone cycle are described. Model output and methods of data analysis are specified. In Sect. 3 the chemistry and photochemistry of the stratosphere are discussed. Section 4 shows the daily ozone cycle and its underlying chemical and photochemical processes at $5 \mathrm{hPa}$. Section 5 describes seasonal effects in the daily ozone cycle. Section 6 describes regional effects in the daily ozone cycle. The conclusions give a brief summary of the results and their implications for a correction of diurnal effects in ozone series.

\section{The Whole Atmosphere Community Climate Model}

The Whole Atmosphere Community Climate Model is a community access model which was developed by the National Center of Atmospheric Research (NCAR) (Garcia et al., 2007; Marsh et al., 2007; Tilmes et al., 2007). The WACCM model consists of individual land, ice, ocean and atmosphere models which interact within the Community Earth System Model (CESM) software framework.

The atmosphere model fully couples chemistry, radiation and dynamics including the processes of chemical heating, gravity wave drag, ionisation and molecular diffusion. 
WACCM calculates ozone which feeds back to the thermal state and dynamics of the modelled atmosphere. The model domain ranges from the Earth's surface to $5.1 \times 10^{-6} \mathrm{hPa}$ $(\sim 150 \mathrm{~km})$ and hence comprises the troposphere, stratosphere, mesosphere and the lower thermosphere. The chemistry module of WACCM is based on the Model of Ozone and Related Chemical Tracers (MOZART v3, Kinnison et al., 2007). It calculates the abundance of 59 neutral species including the $\mathrm{O}_{\mathrm{x}}, \mathrm{NO}_{\mathrm{y}}, \mathrm{HO}_{\mathrm{x}}, \mathrm{Cl}_{\mathrm{y}}$ and $\mathrm{Br}_{\mathrm{y}}$ families. Besides considering chemistry, the photolysis rates of the species are calculated (e.g. $\mathrm{O}_{3}, \mathrm{~N}_{2} \mathrm{O}, \mathrm{H}_{2} \mathrm{O}, \mathrm{CFCs}$ ).

The model was intercompared with other chemistryclimate models during the Chemistry-Climate Model Validation (CCMVal) activity (SPARC Report, 2010) and performed very well. WACCM calculates accurate photolysis rates while considering radiative transfer, aerosol and cloud distributions. For this study we perform free-running simulations of WACCM without nudging meteorological reanalysis data.

\subsection{Numerical simulation}

Numerical simulations for this work were performed utilising version 4 of the WACCM model, which was released in February 2012. The F 2000 WACCM scenario was utilised to simulate 1 year starting from 1 January. The atmosphere and the land model are free-running while ocean, land ice and sea ice models read climatologies.

The analysis deals with atmospheric effects of short timescales compared to common climate-related processes. For this reason, we perform the simulations with a coupling of dynamics and physics with a time step of $15 \mathrm{~min}$, which is half of the standard time resolution of WACCM. Although it is desirable to have even shorter time steps for photochemistry during sunrise, the simulations are limited by computing capacity.

All simulations were carried out with a horizontal resolution of $4^{\circ}$ latitude by $5^{\circ}$ longitude. The model has 66 vertical layers on hybrid-pressure $(\sigma-p)$ coordinates (Phillips, 1957) with a vertical resolution ranging from 1.1 to $2.0 \mathrm{~km}$ in the middle atmosphere. The coordinates are terrainfollowing below the $100 \mathrm{hPa}$ level and isobar above.

\subsection{Model output and data analysis}

In our configuration, the WACCM model produces fourdimensional fields of gases, dynamics and reaction rate coefficients with an output frequency of 1 hour. The entirety of these fields gives a detailed view of the conversion of specific chemical branches. For instance, a generic bimolecular reaction of species $\mathrm{A}$ and $\mathrm{B}$ reacts to a product at the reaction rate $R$, which is given by

$R=k(\mathrm{~A})(\mathrm{B})$, where $k$ refers to the reaction rate coefficient and (X) stands for the concentration of species $\mathrm{X}$. The four-dimensional WACCM fields of $k, \mathrm{~A}$ and B in combination with Eq. (1) yield the reaction rate $R$ at any time and location within the limits of the model resolution. The spatiotemporal fluctuations of the reaction rate are governed by those of the atmospheric gas concentrations and the reaction rate coefficient.

The four-dimensional hourly WACCM output of gases, dynamics and reaction rates is often transferred from universal time (UT) to local solar time meridian (LSTM) by

$\mathrm{LSTM}=\mathrm{UT}+\phi \frac{24 \mathrm{~h}}{360^{\circ}}$,

where $\phi$ refers to longitude in degrees. The $5^{\circ}$ longitudinal resolution of the WACCM simulation corresponds to a resolution of $20 \mathrm{~min}$ in LSTM. For consistency, the hourly WACCM output at each grid point is interpolated to a series with a temporal resolution of $20 \mathrm{~min}$ in UT. After the transformation to LSTM the $20 \mathrm{~min}$ temporal resolution is maintained for the analysis and the illustration in our figures. These resulting four-dimensional fields in LSTM allow us to also study also regional effects, which is an advantage over diurnal variation sampled from different longitudes. In the following, the term "LT" is used as a synonym for the inconvenient "LSTM".

In the middle stratosphere, ozone reaches a minimum and a maximum during a day at a given location. The difference between these extrema is the peak-to-valley difference $D_{\mathrm{O}_{3}}$ :

$D_{\mathrm{O}_{3}}=\mathrm{O}_{3, \max }-\mathrm{O}_{3, \min }$,

where $\mathrm{O}_{3, \text { max }}$ and $\mathrm{O}_{3, \text { min }}$ refer to the extrema within the period from 00:00 to 24:00 LT. In the following, we often use the word "ozone" as a synonym for ozone volume mixing ratio. This convention applies also to other species within this study. Similarly, peak-to-valley differences in temperature are defined as

$D_{\mathrm{T}}=T_{\max }-T_{\min }$,

with $T_{\max }$ and $T_{\min }$ referring to the maximum and the minimum temperature from 00:00 to 24:00 LT.

Within the discussion of regional effects of the ozone variations, longitudinal anomalies in a species $\mathrm{X}$ are defined by

$\mathrm{X}^{\prime}(\lambda, \phi, z, t)=\mathrm{X}(\lambda, \phi, z, t)-\overline{\mathrm{X}}(\lambda, z, t)$,

where $\overline{\mathrm{X}}$ is the zonal mean of $\mathrm{X}$. The arguments $\lambda, \phi, z$ and $t$ refer to latitude, longitude, altitude and time respectively.

\section{Chemical and photochemical reactions}

In a first approach, pure-oxygen photochemistry explains the occurrence of stratospheric ozone. The so-called Chapman 
cycle (Chapman, 1930) is given by the following reactions derived from pure-oxygen photochemistry:

$$
\begin{aligned}
& \left(J_{2}\right) ; \mathrm{O}_{2}+h v \rightarrow \mathrm{O}+\mathrm{O} \\
& \left(J_{2}^{*}\right) ; \mathrm{O}_{2}+h v \rightarrow \mathrm{O}\left({ }^{1} \mathrm{D}\right)+\mathrm{O} \\
& \left(k_{2}\right) ; \mathrm{O}+\mathrm{O}_{2}+\mathrm{M} \rightarrow \mathrm{O}_{3}+\mathrm{M} \\
& \left(k_{3}\right) ; \mathrm{O}+\mathrm{O}_{3} \rightarrow \mathrm{O}_{2}+\mathrm{O}_{2} \\
& \left(k_{5}\right) ; \mathrm{O}\left({ }^{1} \mathrm{D}\right)+\mathrm{O}_{3} \rightarrow \mathrm{O}_{2}+\mathrm{O}_{2} \\
& \left(J_{3}\right) ; \mathrm{O}_{3}+h v \rightarrow \mathrm{O}_{2}+\mathrm{O} \\
& \left(J_{3}^{*}\right) ; \mathrm{O} 3+h v \rightarrow \mathrm{O}_{2}\left({ }^{1} \Delta_{\mathrm{g}}\right)+\mathrm{O}\left({ }^{1} \mathrm{D}\right) \\
& \left(k_{1}\right) ; \mathrm{O}+\mathrm{O}+\mathrm{M} \rightarrow \mathrm{O}_{2}+\mathrm{M} .
\end{aligned}
$$

All reactions are given with their reaction rate coefficients $k_{i}$ and photolysis frequencies $J_{i}$ according to the notation of Brasseur and Solomon (2005). The photolysis of $\mathrm{O}_{3}$ is energetically allowed at wavelengths $\lambda \leq 1180 \mathrm{~nm}$ and mostly takes place in the spectral regions of the Hartley, Huggins and Chappuis bands. Photolysis of $\mathrm{O}_{2}$ occurs for ultraviolet radiation of wavelengths $\lambda \leq 242.4 \mathrm{~nm}$ (Sander et al., 2011).

Stratospheric ozone is reduced by catalytic cycles shown in Eqs. (6-8) where $X$ represents a generic catalyst.

$$
\begin{aligned}
X+\mathrm{O}_{3} & \rightarrow X \mathrm{O}+\mathrm{O}_{2} \\
X \mathrm{O}+\mathrm{O} & \rightarrow X+\mathrm{O}_{2} \\
\mathrm{O}+\mathrm{O}_{3} & \rightarrow \mathrm{O}_{2}+\mathrm{O}_{2} \quad \text { (net reaction) }
\end{aligned}
$$

In this scheme the catalyst destroys an ozone molecule while forming molecular oxygen and becoming oxidised. In a further reaction, the oxidised catalyst reacts with atomic oxygen resulting in an oxygen molecule and a reactivated catalyst. In sum these reactions transform an ozone molecule and atomic oxygen into two oxygen molecules. A continuous repetition of the catalytic cycle can destroy a large number of ozone molecules with a single catalyst (Johnston, 1971). Catalytic cycles are mostly interrupted by deactivation of catalysts into reservoir species (e.g. $\mathrm{HCl}, \mathrm{N}_{2} \mathrm{O}_{5}, \mathrm{ClONO}_{2}$ ) or by transport to the troposphere. For the stratosphere and the mesosphere the catalysts are essentially from the families of $\mathrm{NO}_{\mathrm{y}}$ (Crutzen, 1970; Johnston, 1971) and $\mathrm{HO}_{\mathrm{x}}$ (Bates and Nicolet, 1950). Catalytic ozone depletion is also fostered by halogens of families such as $\mathrm{Cl}_{\mathrm{y}}$ (Stolarski and Cicerone, 1974) and $\mathrm{Br}_{\mathrm{y}}$ (McElroy et al., 1986; Tung et al., 1986; Wofsy et al., 1975).

Chemical and photochemical reactions are handled by the chemistry module of WACCM, which is based on the MOZART model.
The WACCM model solves the continuity equation of ozone, which describes photochemistry and advection by

$$
\begin{aligned}
& \frac{\partial\left(\mathrm{O}_{3}\right)}{\partial t}+\nabla \boldsymbol{\phi}_{\mathrm{O}_{3}} \\
& =k_{2}(\mathrm{M})(\mathrm{O})\left(\mathrm{O}_{2}\right) \\
& -\left(J_{3}+J_{3}^{*}\right)\left(\mathrm{O}_{3}\right)-k_{3}(\mathrm{O})\left(\mathrm{O}_{3}\right)-k_{5}\left(\mathrm{O}\left({ }^{1} \mathrm{D}\right)\right)\left(\mathrm{O}_{3}\right) \\
& -b_{4}(\mathrm{NO})\left(\mathrm{O}_{3}\right)-b_{9}\left(\mathrm{NO}_{2}\right)\left(\mathrm{O}_{3}\right)-a_{2}(\mathrm{H})\left(\mathrm{O}_{3}\right)-a_{6}(\mathrm{OH})\left(\mathrm{O}_{3}\right) \\
& -a_{6 b}\left(\mathrm{HO}_{2}\right)\left(\mathrm{O}_{3}\right)-d_{2}(\mathrm{Cl})\left(\mathrm{O}_{3}\right)-e_{2}(\mathrm{Br})\left(\mathrm{O}_{3}\right),
\end{aligned}
$$

where $\phi_{\mathrm{O}_{3}}$ is the ozone flux. The reactions involving $\mathrm{NO}$, $\mathrm{NO}_{2}, \mathrm{H}, \mathrm{OH}, \mathrm{HO}_{2}, \mathrm{Cl}$ and $\mathrm{Br}$ are parts of catalytic ozone depletion cycles which are limited by the rates of intermediate steps (Johnston and Podolske, 1978).

The reaction and photolysis rates of Eq. (9) are again denoted as in Brasseur and Solomon (2005) and missing definitions of reaction rates are described in Appendix A. For more details about Eq. (9) the reader is referred to Emmons et al. (2010). The concepts of catalytic cycles, null cycles and consumptive sequences leading to differential equations of atmospheric constituents as in Eq. (9) were reviewed by Johnston and Podolske (1978).

\section{The daily ozone cycle}

Earlier studies on the daily ozone cycle of the stratosphere (e.g. Pallister and Tuck, 1983; Herman, 1979; Fabian et al., 1982) indicate a strong connection to chemistry and photochemistry. In this section, we analyse WACCM simulations of chemical and photochemical processes under their coupling to dynamics and the thermal state of the atmosphere. The analysis focuses on $5 \mathrm{hPa}$, where strong diurnal variations of ozone occur in the stratosphere.

The following conversion rates relate to the photochemical sink and source terms of Eq. (9). Figure 1 shows the simulated net ozone conversion rate (black line) for different latitudes on $21 \mathrm{March}$. Additionally, the coloured lines depict contributions of specific cycles. The sum of those cycles (coloured lines) yields the net conversion rate of ozone (black line). The label "Chapman" (blue line) refers to all ozone involving reactions of the pure-oxygen photochemistry (Reactions R3-R7). Within the Chapman cycle, ozone production (Reaction R3) dominates during daytime over ozone reduction (Reactions R4-R7) in the stratosphere at $5 \mathrm{hPa}$. This result is not trivial since the partitioning between ozone and atomic oxygen reverses at mesospheric altitudes leading to minimal ozone during daytime.

Figure 1 demonstrates that the NO cycle (red line) is the dominant catalytic ozone depletion cycle at $5 \mathrm{hPa}$. At lower and middle latitudes, the NO cycle is approximately 2 to 4 times stronger than the $\mathrm{Cl}$ cycle. According to the model simulation, conversion rates of $\mathrm{NO}_{2}, \mathrm{H}, \mathrm{OH}, \mathrm{HO}_{2}$ and $\mathrm{Br}$ catalytic cycles are more than 10 times less compared to the 


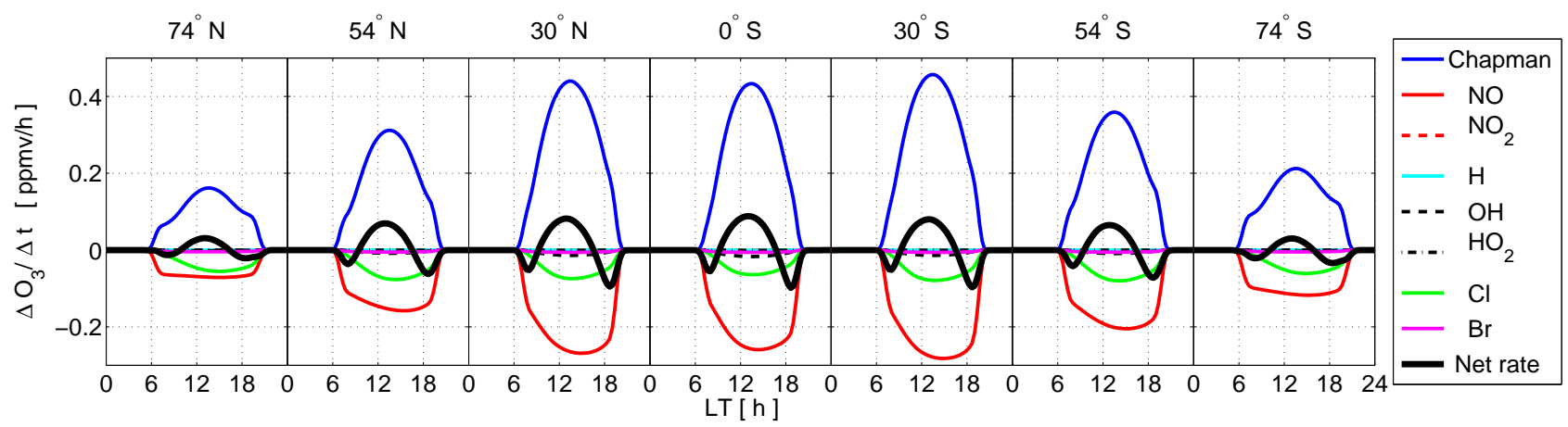

Figure 1. Zonal-mean ozone conversion rates at different latitudes modelled by WACCM (21 March, $5 \mathrm{hPa}$ ). Sunrise and sunset take place at about 06:00 LT and 18:00 LT. The conversion rates of the Chapman cycle (blue lines) include production and depletion of ozone according to Reactions (R3-R7). The red and green lines indicate conversion rates based on the $\mathrm{NO}$ and $\mathrm{Cl}$ catalytic cycles. Further catalytic cycles were taken into account by WACCM but showed negligible ozone conversion rates (catalytic cycles of $\mathrm{NO}_{2}, \mathrm{H}, \mathrm{OH}, \mathrm{HO} 2$ and $\mathrm{Br}$ ). The net conversion rate (black line) is the sum of the conversion rates of all cycles.

NO cycle at $5 \mathrm{hPa}$. The WACCM simulation confirms earlier results of Pallister and Tuck (1983), who identified the $\mathrm{NO}_{\mathrm{y}}$ cycle as the dominant catalytic cycle at altitudes from 26 to $43 \mathrm{~km}$ at noon.

At all latitudes shown in Fig. 1, the net conversion rate results in periods of ozone decrease and accumulation. For instance, at the equator, ozone decreases from sunrise (approximately 06:00 LT) until about 09:00 LT. Subsequently, ozone is accumulated until about 16:00 LT. During the evening ozone decreases until about 21:00 LT.

In Fig. 1 the Chapman cycle and the NO cycle show a dependence on latitude whereas the $\mathrm{Cl}$ cycle is almost constant over latitude. At the equator the conversion rates of the Chapman cycle and the NO cycle are approximately two times stronger than at $74^{\circ} \mathrm{N}$ or $74^{\circ} \mathrm{S}$ on 21 March. The increase of the Chapman cycle and the NO cycle from high to low latitudes is caused by the increase of solar irradiance with decreasing solar zenith angle (Craig and Ohring, 1985). Further, in Fig. 1 the net conversion rate of ozone shows a dependence on latitude. Thus the solar zenith angle is a regulator of diurnal ozone decrease and accumulation at $5 \mathrm{hPa}$ in the stratosphere. The almost constant $\mathrm{Cl}$ cycle over latitude may be attributed to the global distribution of $\mathrm{Cl}$ species. For instance, the abundance of $\mathrm{ClO}$ which is a source of active $\mathrm{Cl}$ is approximately two times higher than at $60^{\circ}$ latitude in the tropics in March (Solomon and Garcia, 1984). The increase of $\mathrm{ClO}$ at mid- and high latitudes may compensate for the effect of the increased solar zenith angle at these latitudes.

Figure 2 shows the simulated daily ozone cycle at $5 \mathrm{hPa}$ for March, June, September and December. The cycles comprise a morning minimum and a late-afternoon maximum. The peak-to-valley difference $D_{\mathrm{O}_{3}}$ (Eq. 3) is approximately $1.5 \%(0.11 \mathrm{ppmv})$ of midnight ozone in December and $5 \%$ $(0.3 \mathrm{ppmv})$ in June derived from zonal-mean data at $50^{\circ} \mathrm{N}$.

A similar increase of ozone during the afternoon was found in a climatology of the daily ozone cycle observed by

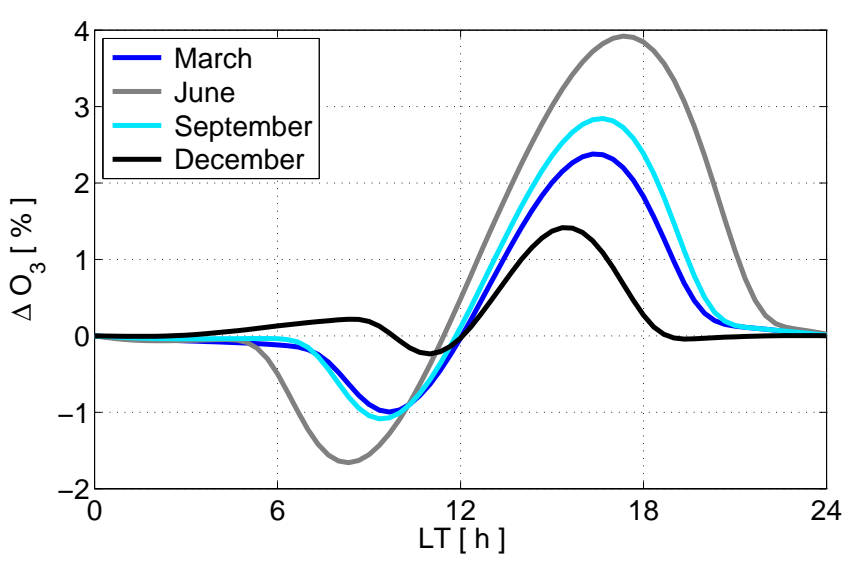

Figure 2. Temporal evolution and seasonal diversity of the daily ozone cycle at $50^{\circ} \mathrm{N}$. The data are zonal means modelled by WACCM at $5 \mathrm{hPa}$. The lines show changes in ozone in monthly means of March, June, September and December relative to the midnight value of ozone.

the ground-based microwave radiometer GROMOS in Bern, Switzerland (Studer et al., 2014). Satellite-based observations from SMILES (Kikuchi et al., 2013), SABER and MLS showed a morning minimum and a late-afternoon maximum in the daily ozone cycle in the tropics and subtropics (Huang et al., 2008; Sakazaki et al., 2013). In Fig. 2 the strength of $D_{\mathrm{O}_{3}}$ differs for March, June, September and December, which indicates a seasonal variation in the daily ozone cycle. The existence of a seasonal variation of the daily ozone cycle was also suggested by Sakazaki et al. (2013). We discuss the seasonal effects in more detail in Sect. 5.

The characteristic morning minimum and the lateafternoon maximum mostly result from chemical and photochemical reactions. For instance, after sunrise NO is activated by photodissociation of $\mathrm{NO}_{2}$ at wavelengths $\lambda \leq$ $402 \mathrm{~nm}$ as shown in Reaction (R9) and to a minor extent by 


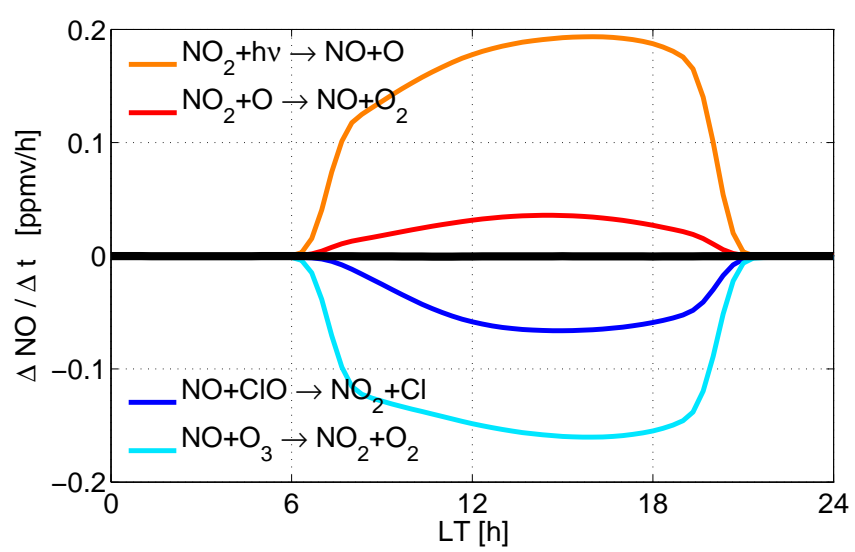

Figure 3. Zonal-mean conversion rates of $\mathrm{NO}$ at $5 \mathrm{hPa}, 21 \mathrm{March}$, $50^{\circ} \mathrm{N}$. The corresponding reactions are given next to the conversion lines. The net conversion rate of NO (black line) show negligible conversion rate since common $\mathrm{NO}$ changes at the solar terminator are from 0 to approximately $10 \mathrm{ppbv}$. Reactions with absolute conversion rates less than $5 \mathrm{ppbv} \mathrm{h}^{-1}$ are omitted.

Reaction (R10).

$$
\begin{array}{r}
\left(J_{\mathrm{NO}_{2}}\right) ; \mathrm{NO}_{2}+h v \rightarrow \mathrm{NO}+\mathrm{O} \\
\left(b_{3}\right) ; \mathrm{NO}_{2}+\mathrm{O} \rightarrow \mathrm{NO}+\mathrm{O}_{2}
\end{array}
$$

The activated NO rapidly decreases ozone after sunrise by means of the NO cycle. During the morning, ozone is rebuilt and further increased due to the photodissociation of oxygen molecules and the ozone production given by Reactions (R1) and (R3).

Figure 3 shows the NO conversion rates decomposed into chemical and photochemical reactions on 21 March. Reactions with absolute conversion rates less than $5 \mathrm{ppbv} \mathrm{h}^{-1}$ are omitted in Fig. 3. According to the model simulation, $\mathrm{NO}$ is mainly activated by photodissociation of $\mathrm{NO}_{2}$ given by Reaction (R9) (orange line) and marginally by Reaction (R10) (red line). Most of the activated NO directly decreases ozone (cyan line) by means of the NO cycle. To a minor extent NO couples to the $\mathrm{Cl}_{\mathrm{y}}$ family and activates $\mathrm{Cl}$ by Reaction (R11) (blue line).

$\left(d_{4}\right) ; \mathrm{ClO}+\mathrm{NO} \rightarrow \mathrm{Cl}+\mathrm{NO}_{2}$

Similar results were derived from photochemical box models (e.g. Pallister and Tuck, 1983). The three-dimensional chemistry-climate model WACCM confirms these results on a global scale and under inclusion of dynamical and thermal effects in a fully coupled atmosphere model with realistic distributions of trace gases, transport processes, mixing, gravity waves, planetary waves, tides and wave-mean flow interactions.

The NO production over daytime strongly depends on $\mathrm{NO}_{2}$ at $5 \mathrm{hPa} . \mathrm{NO}_{2}$ in turn reacts with further atmospheric trace gases as nitrogen compounds. For instance, $\mathrm{N}_{2} \mathrm{O}_{5}$ is assembled during night-time by removing $\mathrm{NO}_{2}$ from the strato-

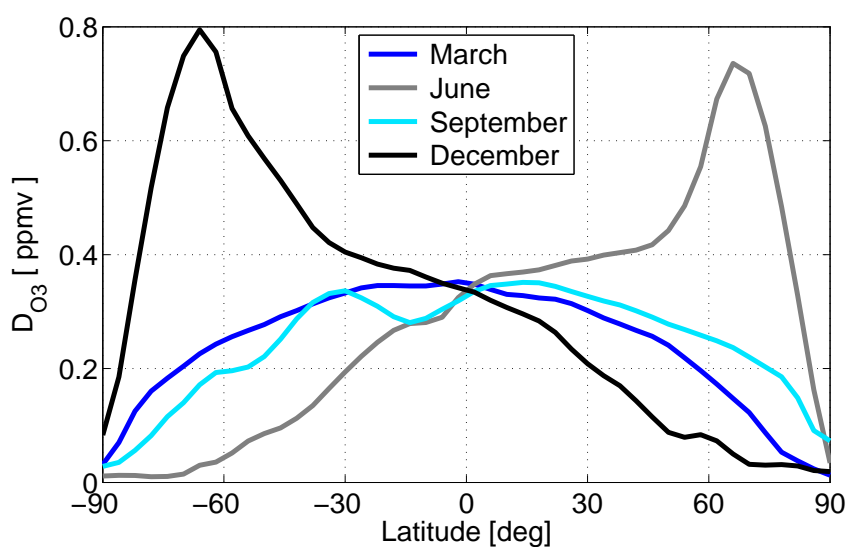

Figure 4. Zonal mean of peak-to-valley difference $D_{\mathrm{O}_{3}}$ (Eq. 3) as a function of latitude at $5 \mathrm{hPa}$ modelled by WACCM. The lines show monthly mean $D_{\mathrm{O}_{3}}$ for March, June, September and December.

sphere by thermolecular Reaction (R12).

$$
\begin{array}{cl}
\left(b_{12}\right) ; & \mathrm{NO}_{2}+\mathrm{NO}_{3}+\mathrm{M} \rightarrow \mathrm{N}_{2} \mathrm{O}_{5}+\mathrm{M} \\
\left(b_{32}\right) ; & \mathrm{N}_{2} \mathrm{O}_{5}+\mathrm{M} \rightarrow \mathrm{NO}_{3}+\mathrm{NO}_{2}+\mathrm{M} \\
\left(J_{\mathrm{N}_{2} \mathrm{O}_{5}}^{a}\right) ; & \mathrm{N}_{2} \mathrm{O}_{5}+h v \rightarrow \mathrm{NO}_{3}+\mathrm{NO}_{2}
\end{array}
$$

During daytime $\mathrm{N}_{2} \mathrm{O}_{5}$ is thermally decomposed or photodissociated by Reactions (R13) and (R14). In this context, $\mathrm{N}_{2} \mathrm{O}_{5}$ is a temporary reservoir for reactive $\mathrm{NO}_{\mathrm{x}}\left(\mathrm{NO}\right.$ and $\left.\mathrm{NO}_{2}\right)$. The coupling of $\mathrm{NO}_{2}$ to the reservoir gives a contribution to the diurnal $\mathrm{NO}_{\mathrm{x}}$ cycle (Walker and Dudhia, 2011) and in turn influences the daily ozone cycle. For instance, ozone decrease through the NO cycle increases from the morning to the afternoon. $\mathrm{NO}_{\mathrm{x}}$ which is in the form of $\mathrm{N}_{2} \mathrm{O}_{5}$ in the early morning is slowly released from the reservoir and increases the conversion rates of the $\mathrm{NO}$ cycle during daytime.

Sources of $\mathrm{NO}_{\mathrm{x}}$ in the stratosphere are, for instance, natural and anthropogenic surface emissions of $\mathrm{N}_{2} \mathrm{O}$. These emissions of $\mathrm{N}_{2} \mathrm{O}$ ascend into the stratosphere, where $\mathrm{NO}_{\mathrm{x}}$ is increased by means of Reaction (R15).

$\left(b_{39}\right) ; \mathrm{N}_{2} \mathrm{O}+\mathrm{O}\left({ }^{1} \mathrm{D}\right) \rightarrow 2 \mathrm{NO}$

For this reason $\mathrm{N}_{2} \mathrm{O}$ is an important regulator of stratospheric ozone. In the lower and middle stratosphere the chemical and dynamical lifetimes of $\mathrm{NO}_{\mathrm{x}}$ are comparable so that transport can play a role. $\mathrm{N}_{2} \mathrm{O}$ passes the tropopause mostly in the tropics and is globally distributed in the stratosphere by the Brewer-Dobson circulation.

\section{Seasonal variations in the daily ozone cycle}

Figure 4 shows $D_{\mathrm{O}_{3}}$ over latitude for March, June, September and December. In March and September $D_{\mathrm{O}_{3}}$ is decreasing from the equator $(0.35 \mathrm{ppmv})$ towards the poles $(<0.07 \mathrm{ppmv})$. Surprisingly, June and December show significantly enhanced $D_{\mathrm{O}_{3}}$ at high latitudes in the summer 


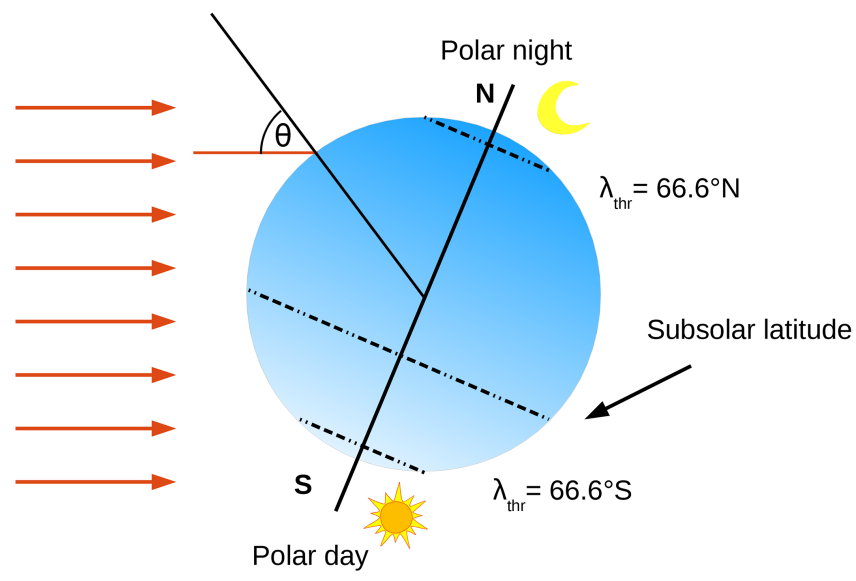

Figure 5. Geometry of incident solar radiation and Earth rotation axis at the December solstice. The threshold latitudes $\lambda_{\text {thr }}$ separates the polar day and polar night regions from regions of alternating day and night periods. $\Theta$ is to the solar zenith angle.

hemisphere. For instance, $D_{\mathrm{O}_{3}}$ peaks in the simulation data at $66^{\circ} \mathrm{S}(0.79 \mathrm{ppmv}, 14.5 \%)$ in December and at $66^{\circ} \mathrm{N}$ $(0.74$ ppmv, $11.7 \%)$ in June.

The simulation data of March and September (blue and cyan lines) reinforce the assumed regulation of ozone decrease and accumulation $\left(D_{\mathrm{O}_{3}}\right)$ by the solar zenith angle at $5 \mathrm{hPa}$. Nevertheless, the solar zenith angle cannot explain the high values of $D_{\mathrm{O}_{3}}$ around the polar circle in summer.

Figure 2 illustrates the seasonal variation in $D_{\mathrm{O}_{3}}$ in the Northern Hemisphere at $50^{\circ} \mathrm{N}$. In June the small solar zenith angle and the long sunshine duration (period of insolation over daytime) lead to stronger effects in $D_{\mathrm{O}_{3}}$ than a short day with high solar zenith angle in December. The sunshine duration strongly depends on season at higher latitudes and is constant at the equator. The seasonal altering of the sunshine duration impacts the photochemical system in the stratosphere. A long sunshine duration leads to a long period of ozone accumulation and hence to enhanced $D_{\mathrm{O}_{3}}$.

Based on the sunshine duration, the solar zenith angle and with the aid of Fig. 5, we discuss the effects of $D_{\mathrm{O}_{3}}$ in December, including the strong effect in the summer hemisphere at high latitudes. Figure 5 depicts the geometry of the Earth's axis and the solar radiation at the December solstice. The solar zenith angle is the angle between the sun's ray and the zenith ray as shown in Fig. 5. The threshold latitude $\left(\lambda_{\text {thr }}\right)$ assigned in Fig. 5 refers to the border of the polar day or polar night. Figure 5 includes four major regions of different characteristics with respect to sunshine duration and solar zenith angle:

- Polar-night area: no solar radiation.

- Midlatitudes and tropics: sunshine duration increases from the northern winter to the southern summer hemisphere. Solar zenith angle at noon is zero at $23.4^{\circ} \mathrm{S}$ (subsolar latitude).

- Polar-day area: sunshine duration of $24 \mathrm{~h}$ with sun at low elevation and small changes in the solar zenith angle.

- South Pole: sunshine duration of $24 \mathrm{~h}$ with constant solar zenith angle.

The four characteristic regions can be related to $D_{\mathrm{O}_{3}}$ over latitude in December as shown in Fig. 4 (black line). In December, $D_{\mathrm{O}_{3}}$ is marginal at the North Pole and the northern polar region due to absent solar radiation. Equatorwards of the Arctic Circle, the sunshine duration and the solar zenith angle show different behaviour. The solar zenith angle decreases until $23.4^{\circ} \mathrm{S}\left(\Theta=0^{\circ}\right)$ and increases towards the South Pole. The sunshine duration increases from $0 \mathrm{~h}$ at the Arctic Circle to $24 \mathrm{~h}$ at the Antarctic Circle (polar day). At high latitudes, the gradient in sunshine duration is higher than in the tropics. According to the model simulation, this region shows an almost steady increase of $D_{\mathrm{O}_{3}}$ from the Arctic Circle towards the Antarctic Circle where $D_{\mathrm{O}_{3}}$ peaks. The model resolution is too low to specify whether the peak in $D_{\mathrm{O}_{3}}$ is poleward or equatorward of the Antarctic Circle. We assume that the maximum of $D_{\mathrm{O}_{3}}$ is slightly shifted equatorwards of the Antarctic Circle, where ozone decreases during a short night period. Poleward of the Antarctic Circle the sunshine duration is $24 \mathrm{~h}$ with small variations in the solar zenith angle. This situation leads to decreasing $D_{\mathrm{O}_{3}}$ and marginal $D_{\mathrm{O}_{3}}$ at the South Pole.

The dependence of the daily ozone cycle on the solar zenith angle and the sunshine duration mostly explains the complex picture of the seasonal variation in the daily ozone cycle over the globe as described above by means of the WACCM simulation. Based on the solar zenith angle and the sunshine duration most seasonal effects of the ozone cycle in the stratosphere can be explained qualitatively. To the authors' knowledge, the global seasonal behaviour of the daily ozone cycle has not been comprehensively described in the literature. Previous simulation studies were focused on northern midlatitudes (Pallister and Tuck, 1983). Observational studies (Kikuchi et al., 2013) presented the daily ozone cycle of the tropics and midlatitudes or local data (Studer et al., 2014).

Figure 6 gives a complete view of the seasonal change of $D_{\mathrm{O}_{3}}$ as function of day of year (DOY) and geographic latitude as simulated by WACCM. In addition, the sunshine duration (dashed contours) and the solar zenith angle (solid contours) are given as contours in Fig. 6. The strong effects of $D_{\mathrm{O}_{3}}$ at the border of the polar day are present over a period of approximately 80-100 days and are confirmed by observations of a ground-based microwave radiometer at $\mathrm{Ny}$ Ålesund, Svalbard (Palm et al., 2013). 


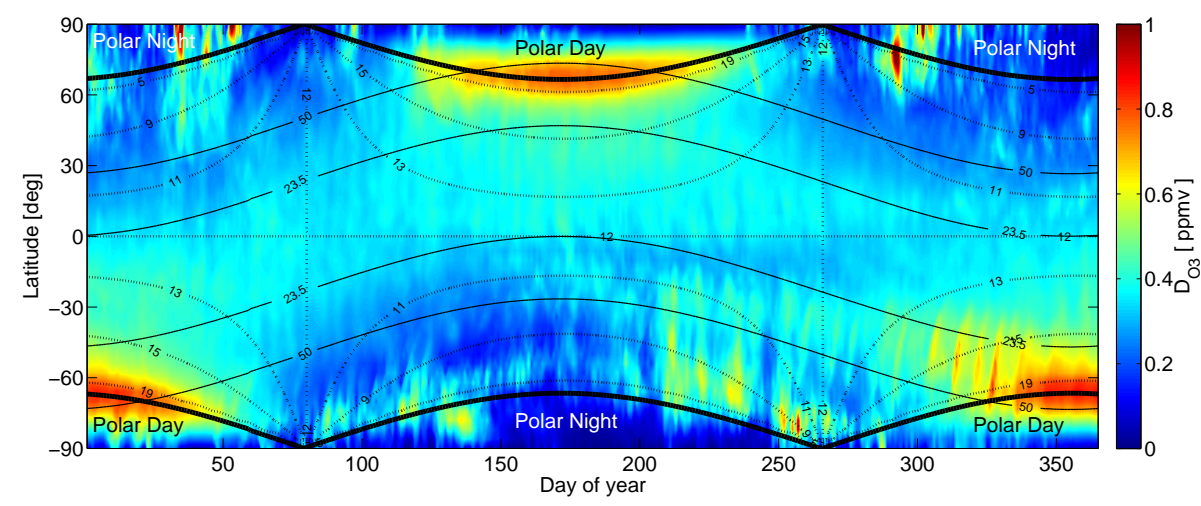

Figure 6. Seasonal changes in the strength of the daily ozone cycle at $5 \mathrm{hPa}$. The figure shows zonal-mean $D_{\mathrm{O}_{3}}$ as a function of day of year and latitude derived from WACCM. The overlaid solid contours refer to the solar zenith angle at noon. Thick solid lines depict the borders of the polar day and polar night. Dashed contours show the sunshine duration given in hours.

In the polar regions in winter, Fig. 6 shows fluctuations in $D_{\mathrm{O}_{3}}$ which cannot be explained by photochemistry. We relate these effects to advection at diurnal and shorter timescales, which is supported by the strong gradients in the ozone field at the polar vortex. Technically, the continuity equation of ozone and other species is fully solved by the WACCM model. However, we question whether WACCM can adequately simulate the effects, since realistic advection at diurnal and shorter timescales requires an almost perfect representation of the main coupling processes of the atmospheric layers (e.g. 2-day waves, sudden stratospheric warmings and gravity waves).

For instance, in the middle atmosphere, vertically propagating gravity waves from below play a key role in dynamics. The gravity waves are excited when stable stratified air flows over orography or by internal heating or shear (Garcia et al., 2007). These waves show a growing momentum flux with height and deposit heat or momentum to the background state while dissipating in the middle atmosphere. The WACCM model incorporates a gravity wave parametrisation, solving for a spectrum of monochromatic waves and for those generated by flow over orography (Garcia et al., 2007). The parameters of the gravity waves are tuned to simulate basic climatological features as temperature and dynamics consistent with observations (Garcia et al., 2007). Richter et al. (2008) found that WACCM at a low spatial resolution of $4^{\circ}$ latitude by $5^{\circ}$ longitude shows less variability in the stratosphere than at higher model resolutions (e.g. gravity wave drag is about $25 \%$ enhanced). Although higher resolution increases variability, it does not improve the representation of the mean wind and temperature in the stratosphere (Richter et al., 2008). We infer that the $4^{\circ}$ latitude by $5^{\circ}$ longitude resolution is well tuned to generate good agreement with climatologies, but it seems likely that gravity-wave-induced advection processes on timescales of 1 day or less are underestimated in our free-running WACCM simulation. Here, we can state that the free-running WACCM simulation shows weak sig- natures of diurnal ozone variations at the polar vortex which are possibly caused by short-term, periodic advection processes in combination with strong, spatial ozone gradients. Further investigations with a nudged model or reanalysis data are planned.

With regard to satellite-derived ozone trend estimates, diurnal sampling effects are most critical at high latitudes during summer. However, since the expected ozone trends are of the order of $1 \%$ per decade or less (Garny et al., 2013; Chehade et al., 2014), a thorough correction of the diurnal sampling effects in time series of stratospheric ozone is necessary at any location. Such a correction could be guided by a chemistry-climate model.

\section{Regional effects of the daily ozone cycle}

The daily ozone cycle has regional variations in $D_{\mathrm{O}_{3}}$ at $5 \mathrm{hPa}$. The origin of the regional variation is manifold. Chemical, dynamical and thermal effects result in synoptic-scale variations of the daily ozone cycle. In order to reveal and quantify the mechanisms, we analysed the three-dimensional WACCM monthly mean data with a focus on regional modulations.

Figure $7 \mathrm{a}$ and $\mathrm{d}$ shows the strength of the daily ozone cycle in the stratosphere depending on latitude and longitude as simulated by WACCM for March, June, September and December. In addition, contour lines depict the strength of diurnal temperature variations $D_{\mathrm{T}}$. Figure $7 \mathrm{a}$ and d comprises the seasonal characteristics of the daily ozone cycle previously discussed in Sect. 5. For instance, Fig. 7a shows increasing $D_{\mathrm{O}_{3}}$ from the poles towards the equator. The strong daily ozone cycle at high latitudes in the summer hemisphere appears in Fig. 7b and d which shows $D_{\mathrm{O}_{3}}$ in June and December. Moreover, Fig. 7a-d contains regional effects of a synoptic scale which are superposed on the global pattern of the daily ozone cycle. In the following subsections, the main sources of regional modulations are presented. 


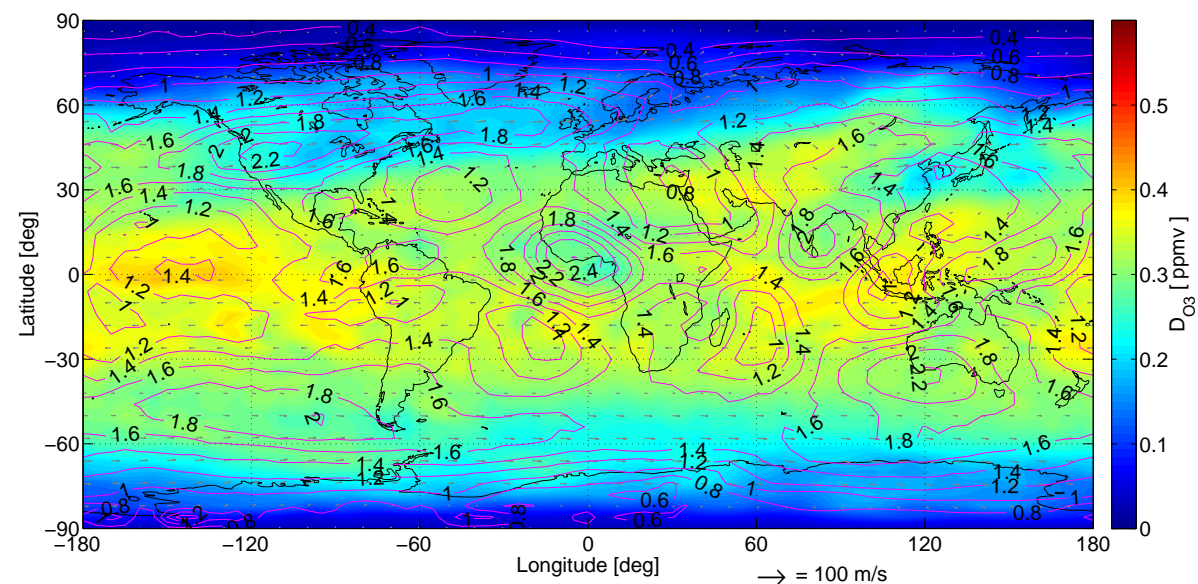

Figure 7a. Monthly mean modelled $D_{\mathrm{O}_{3}}$ at $5 \mathrm{hPa}$ in March as a function of longitude and latitude. A daytime average of horizontal wind (grey arrows) from 09:00 to 15:00 LT is overlaid and a reference for wind speed is given near the $x$ axis. The magenta contour lines refer to the peak-to-valley difference $D_{\mathrm{T}}$ in temperature given in $\mathrm{K}$.

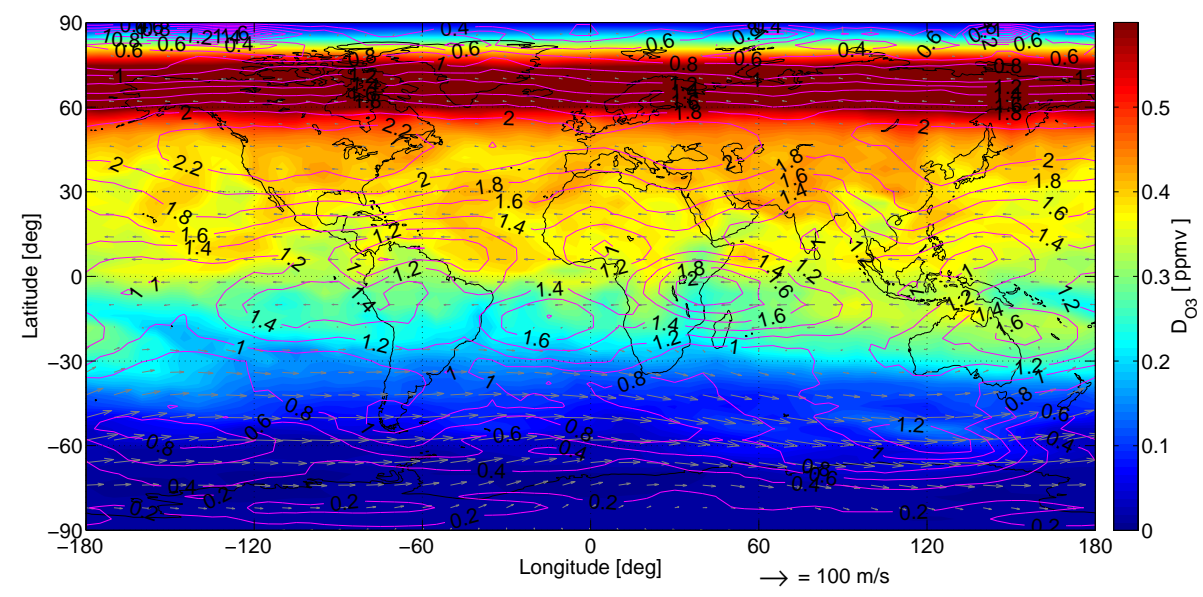

Figure 7b. Same as Fig. 7a with simulation data from June.

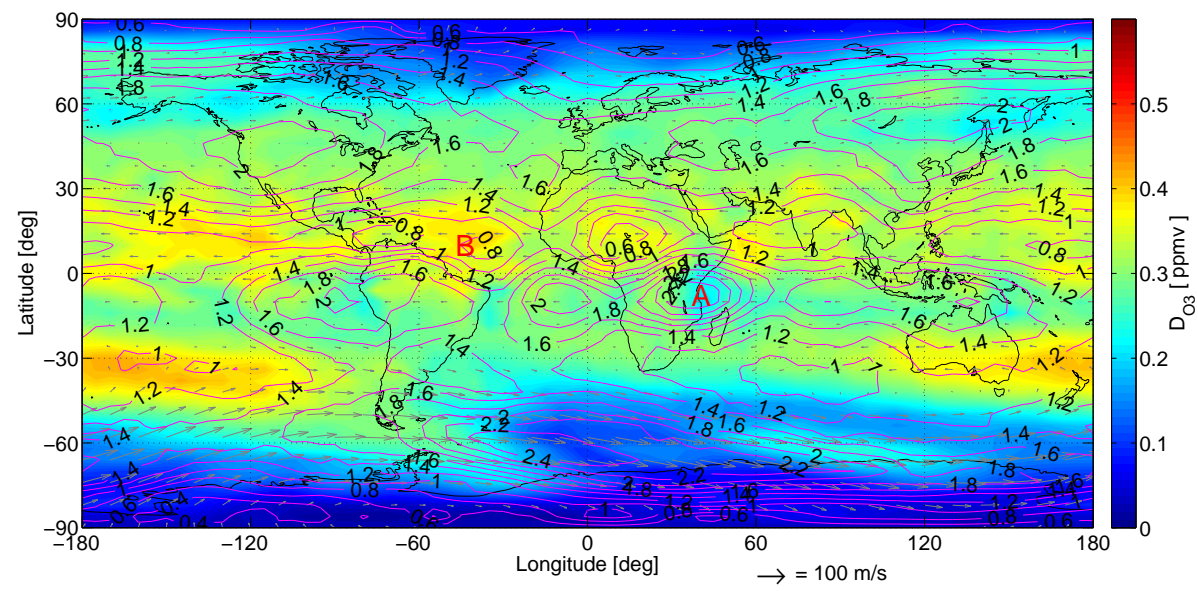

Figure 7c. Same to Fig. 7a with simulation data from September. Temperature-correlated effects of region A and B are discussed in Sect. 6.1. 


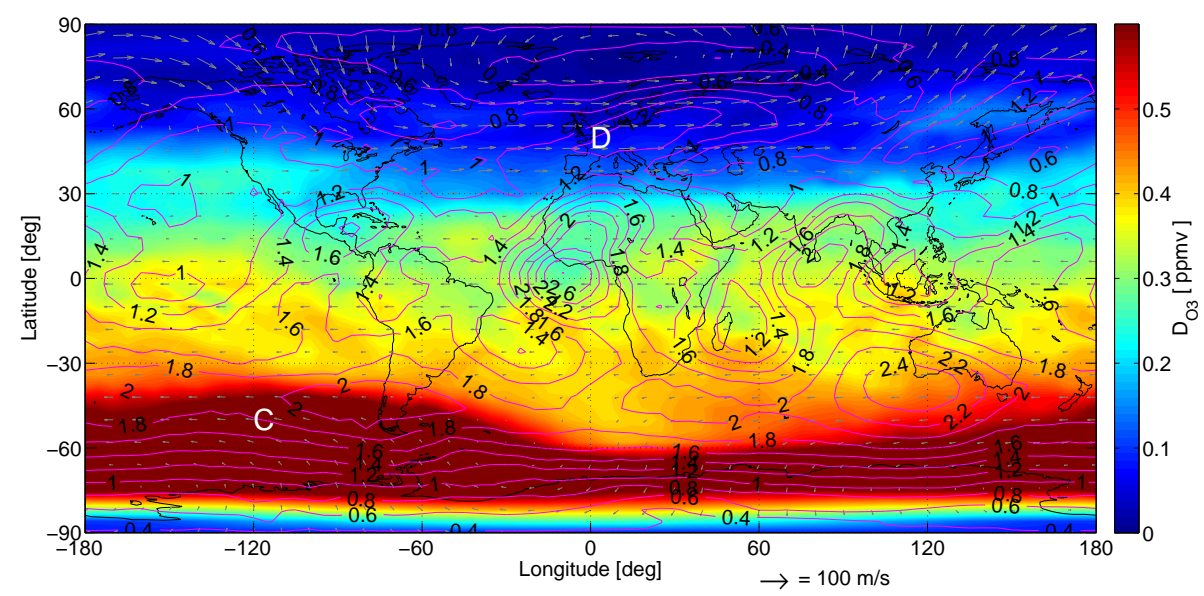

Figure 7d. Same to Fig. 7a with simulation data from December. The effects in Regions C and D are discussed in Sects. 6.2 and 6.3.

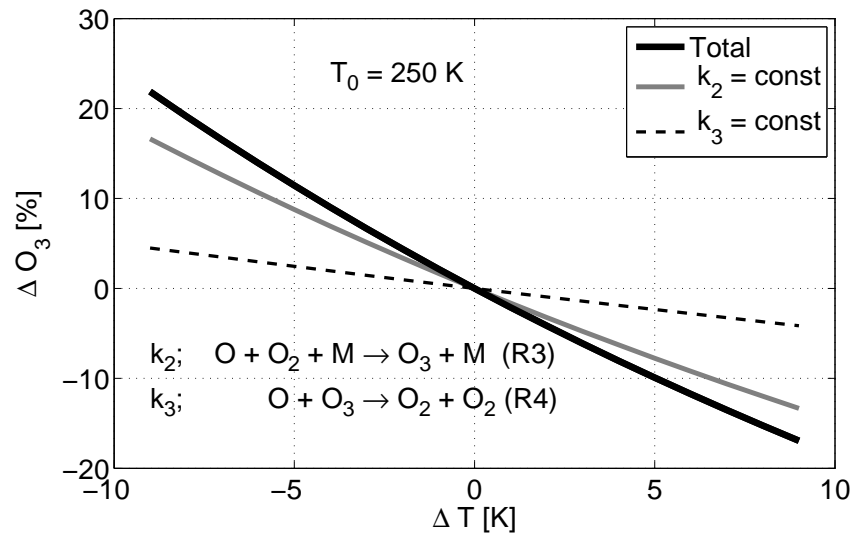

Figure 8. Ozone variations induced by temperature variations in a pure-oxygen atmosphere. "Total" denotes the result obtained for variable, temperature-dependent reaction rate coefficients $k_{2}(T)$ and $k_{3}(T)$.

\subsection{Anti-correlation of $D_{\mathrm{O}_{3}}$ and $D_{\mathrm{T}}$}

Ozone has a major impact on the vertical temperature gradient of the atmosphere, called lapse rate. The heating due to absorption of ultraviolet radiation explains the positive lapse rate of the stratosphere. At the same time, ozone varies with ambient temperature since ozone photochemistry strongly depends on temperature. Thus we expect a close connection of diurnal temperature variations and the daily ozone cycle in the stratosphere.

In pure-oxygen photochemistry, the temperaturedependent rate coefficients $k_{2}$ and $k_{3}$ of Reactions (R3) and (R4) are the main cause of the anti-correlation of ozone and temperature variations (e.g. Froidevaux et al., 1989; Craig and Ohring, 1985). In the stratosphere at $5 \mathrm{hPa}$, ozone is approximately in photochemical equilibrium so that the determination of ozone reduces to Eq. (10), where M refers to the molecule concentration of air (Brasseur and Solomon,
2005). Based on the photochemical equilibrium, the impact of stratospheric temperature variations on ozone can be assessed by

$\mathrm{O}_{3}=\mathrm{O}_{2} \sqrt{\frac{k_{2}}{k_{3}} \frac{J_{2}}{J_{3}} \mathrm{M}}$.

Figure 8 shows the dependence of ozone on temperature variations according to a pure-oxygen atmosphere, described by Eq. (10). Temperature dependencies of oxygen, photolysis rates and air density are neglected. The reference temperature $\left(\mathrm{T}_{0}\right)$ of $250 \mathrm{~K}$ is a realistic temperature of the stratosphere. The analytic expressions of the temperature-dependent rate coefficients $k_{2} \propto(300 / T)^{2.4}$ and $k_{3} \propto \exp (-2060 / T)$ correspond to the model simulation (Kinnison et al., 2007). Our estimation shows an anti-correlation of ozone and temperature of approximately $-2.15 \% \mathrm{~K}^{-1}$ in the stratosphere (Fig. 8). Considering an average tropical ozone volume mixing ratio of $9.23 \mathrm{ppmv}$ (derived from model data), we get an anti-correlation of $-0.20 \mathrm{ppmv} \mathrm{K}^{-1}$. The temperature-induced ozone change is mainly based on Reaction (R4) $(77 \%)$ and less on Reaction (R3) $(23 \%)$. These results indicate that an anticorrelation of temperature and ozone appears in the stratosphere and that Reaction (R4) is sensitive to temperature variations.

The apparent diurnal temperature variations in the stratosphere are mainly due to migrating and non-migrating atmospheric tides. The WACCM data show temperature variations in the stratosphere of up to a few K (not explicitly shown), which are in rough agreement to observations (e.g. Huang et al., 2010; Sakazaki et al., 2012). In addition, WACCM and the observations often show a temperature maximum in the late afternoon at $5 \mathrm{hPa}$. Thus, diurnal temperature variations can affect the strength of the daily ozone cycle.

In order to assess these effects, it is assumed diurnal variations of ozone and temperature are in phase. In this case, the 


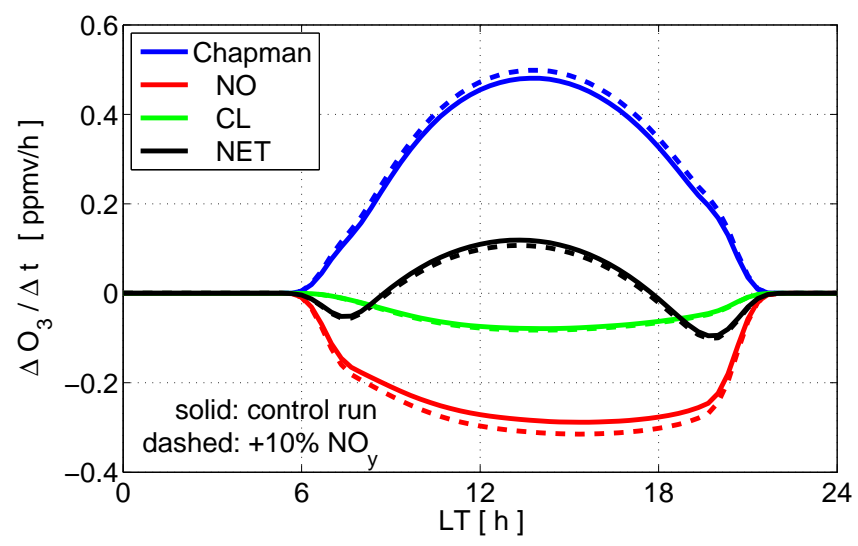

Figure 9. Zonal-mean conversion rates of ozone derived from a simulation with $10 \%$ more initial $\mathrm{NO}_{\mathrm{y}}$ concentration and a control simulation on $1 \mathrm{January,} 5 \mathrm{hPa}, 22^{\circ} \mathrm{N}$.

Table 1. Relation of $D_{\mathrm{T}}$ and $D_{\mathrm{O}_{3}}$ in the tropics. The anomalies with respect to the tropical mean are given by $D_{\mathrm{T}}^{\prime}$ and $D_{\mathrm{O}_{3}}^{\prime}$. Regions $\mathrm{A}$ and $\mathrm{B}$ are indicated in Fig. 7c.

\begin{tabular}{lcr}
\hline Region & \multicolumn{1}{c}{$D_{\mathrm{O}_{3}} / D_{\mathrm{T}}$} & \multicolumn{1}{c}{$D_{\mathrm{O}_{3}}^{\prime} / D_{\mathrm{T}}^{\prime}$} \\
\hline Tropical mean: & $0.34 \mathrm{ppmv} / 1.34 \mathrm{~K}$ & \\
African coast (A): & $0.20 \mathrm{ppmv} / 2.57 \mathrm{~K}$ & $-0.14 \mathrm{ppmv} / 1.23 \mathrm{~K}$ \\
Atlantic Ocean (B): & $0.40 \mathrm{ppmv} / 0.76 \mathrm{~K}$ & $0.06 \mathrm{ppmv} /-0.58 \mathrm{~K}$ \\
\hline
\end{tabular}

strength of the daily ozone cycle is damped by the temperature tide. Or to be more precise, we expect that a $D_{\mathrm{T}}$ value of $1 \mathrm{~K}$ will lead to a $2.15 \%$ decrease in $D_{\mathrm{O}_{3}}$ (as derived from Eq. 10).

On the other hand, we can directly infer from the temperature and ozone distributions of WACCM whether regional anti-correlations between $D_{\mathrm{T}}$ and $D_{\mathrm{O}_{3}}$ exist. In Fig. 7c we find regional anti-correlations of $D_{\mathrm{T}}$ (magenta contours) and $D_{\mathrm{O}_{3}}$ in the tropics in September. On average, the strength of a tropical daily ozone cycle is $0.35 \mathrm{ppmv}$ at $5 \mathrm{hPa}$ and is attended by an average temperature variation of $1.34 \mathrm{~K}$. A regionally damped daily ozone cycle occurs on the east coast of Africa (Fig. 7c, Region A). In contrast, a regionally stronger daily ozone cycle resides in the Atlantic Ocean, east of the Caribbean (Fig. 7c, Region B). The values of $D_{\mathrm{T}}$ and $D_{\mathrm{O}_{3}}$ in Regions A and B and their deviations from the tropical average are summarised in Table 1. From the data of Table 1 we derive an anti-correlation of $D_{\mathrm{T}}$ and $D_{\mathrm{O}_{3}}$ of approximately -0.11 ppmv K $^{-1}$.

The simplified Eq. (10) and the WACCM simulation yield an anti-correlation of $D_{\mathrm{T}}$ and $D_{\mathrm{O}_{3}}$ which is of the same order of magnitude and certainly not negligible. In addition the WACCM simulation clearly shows strong, regional variations of $D_{\mathrm{T}}$.

Our analysis demonstrates the impact of temperature variations on the daily ozone cycle. The interconnections of dynamics, chemistry and photochemistry in chemistry-climate

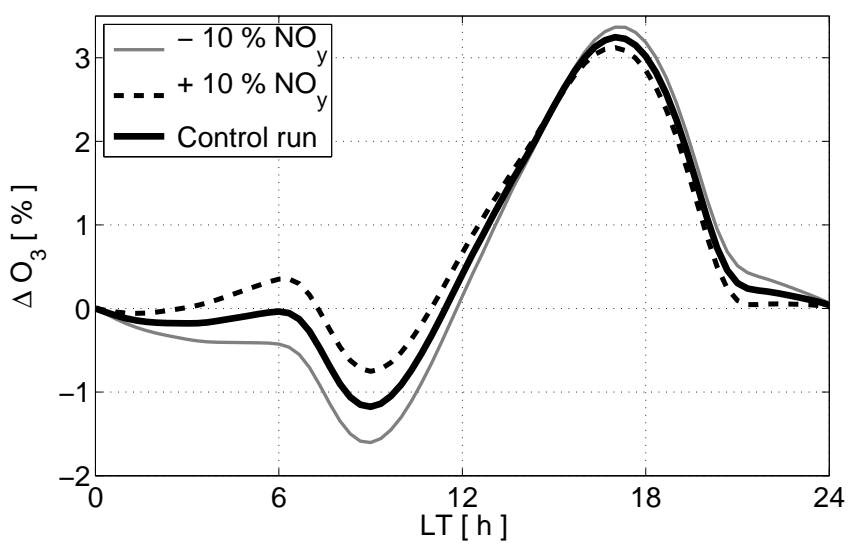

Figure 10. Daily ozone cycles derived from simulations with $\pm 10 \%$ initial $\mathrm{NO}_{\mathrm{y}}$ concentration and a control simulation shown for 1 January, $5 \mathrm{hPa}, 22^{\circ} \mathrm{N}$.

models may help to correct these effects in satellite data utilised for ozone trend estimation. However, the high spatiotemporal variability of atmospheric tides is a challenge for a reliable correction of diurnal effects in ozone trend estimates.

\subsection{Regional $\mathrm{NO}$ and $\mathrm{O}_{3}$ variability and its impact on $\mathrm{D}_{\mathrm{O}_{3}}$}

In Sect. 4 it was argued that the Chapman cycle and the NO cycle cause most of the net ozone conversion rate at $5 \mathrm{hPa}$. Thus, we expect that regional variations of $\mathrm{O}_{3}$ and NO may have an impact on the strength of the daily ozone cycle. In order to understand the regional variations of $\mathrm{O}_{3}$ and $\mathrm{NO}$, it is desirable to study the families of $\mathrm{O}_{\mathrm{x}}$ and $\mathrm{NO}_{\mathrm{y}}$ instead of chemical reactions (e.g. Johnston and Podolske, 1978). Model simulations with globally altered initial $O_{x}$ and $\mathrm{NO}_{\mathrm{y}}$ concentrations give information about influences of changes in trace gases on the resulting daily ozone cycle and $D_{\mathrm{O}_{3}}$. We performed model simulations with altered $\mathrm{O}_{\mathrm{x}}$ and $\mathrm{NO}_{\mathrm{y}}$ concentrations in the initial atmosphere of the $1 \mathrm{Jan}-$ uary at 00:00 UT (model date) and a control simulation without changes in the initial atmospheric conditions. We altered concentrations of $\mathrm{NO}_{\mathrm{y}}$ in order to preserve the concentration ratio of $\mathrm{NO}_{\mathrm{x}} / \mathrm{NO}_{\mathrm{y}}$. The ratio is often used to indicate the ability of $\mathrm{NO}_{\mathrm{x}}$ to destroy ozone in the stratosphere (Brasseur and Solomon, 2005). Equations (11-13) define the sums of nitrogen compounds $\mathrm{NO}_{\mathrm{x}}$ and $\mathrm{NO}_{\mathrm{y}}$ as well as $\mathrm{O}_{\mathrm{x}}$.

$$
\begin{aligned}
& \mathrm{O}_{\mathrm{x}}=\mathrm{O}+\mathrm{O}_{3} \\
& \mathrm{NO}_{\mathrm{x}}=\mathrm{NO}+\mathrm{NO}_{2} \\
& \mathrm{NO}_{\mathrm{y}}=\mathrm{N}+\mathrm{NO}+\mathrm{NO}_{2}+\mathrm{NO}_{3}+2 \mathrm{~N}_{2} \mathrm{O}_{5}+\mathrm{HNO}_{3} \\
& \quad+\mathrm{HO}_{2} \mathrm{NO}_{2}+\mathrm{ClONO}_{2}+\mathrm{BrONO}_{2}
\end{aligned}
$$

The ozone conversion rates for $+10 \%$ initial $\mathrm{NO}_{\mathrm{y}}$ concentration are shown in Fig. 9. The depletion rate of the NO cycle (dashed red line) is higher than in the control simulation 


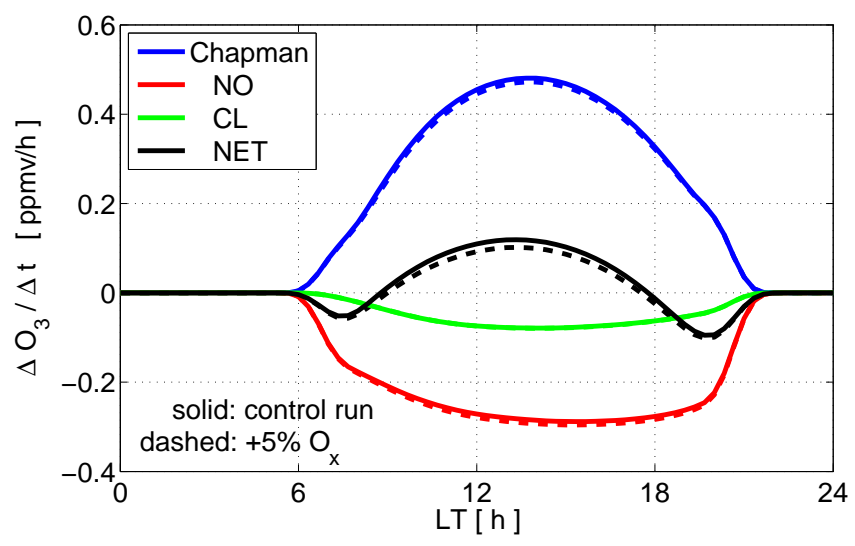

Figure 11. Zonal-mean conversion rates of ozone derived from a simulation with $5 \%$ more initial $\mathrm{O}_{\mathrm{x}}$ concentration and a control simulation on 1 January, $5 \mathrm{hPa}, 22^{\circ} \mathrm{N}$.

data (solid red line) due to higher initial NO concentration. The slightly increased ozone conversion rate of the Chapman cycle (dashed blue line) is related to the initially enhanced $\mathrm{NO}_{2}$ concentration. After sunrise, more $\mathrm{NO}_{2}$ is photodissociated by Reaction (R9) and provides more atomic oxygen for ozone production by means of Reaction (R3). Thus, the ratio of ozone production and depletion within the Chapman cycle changes slightly in favour of ozone production.

Figure 10 compares the daily ozone cycles on 1 January derived from simulations of $\pm 10 \%$ initial $\mathrm{NO}_{\mathrm{y}}$ concentration and the control simulation. All simulations comprise the morning minimum and the late-afternoon maximum at comparable LT as discussed in a previous section. Lower (higher) $\mathrm{NO}_{\mathrm{y}}$ concentration results in more (less) assembled ozone and hence increased (decreased) $D_{\mathrm{O}_{3}}$ respectively.

In a similar manner, we analyse influences of altered $\mathrm{O}_{\mathrm{x}}$ concentrations in the initial atmosphere on the daily ozone cycle. Figure 11 shows the ozone conversion rates for $+5 \%$ $\mathrm{O}_{\mathrm{x}}$ concentration on 1 January. The conversion rate of the Chapman cycle is lower (dashed blue line) compared to the data of the control simulation (blue line). Hence, the ratio of ozone production and depletion within the Chapman cycle changes in favour of ozone depletion. Further, the depletion rate of the NO cycle (dashed red line) is higher compared to the control simulation data (solid red line). This behaviour can be derived from Eq. (9) where ozone depletion by NO is linear in ozone. Finally, Fig. 12 shows the daily ozone cycles derived from simulations with $\pm 5 \%$ initial $\mathrm{O}_{\mathrm{x}}$ concentration and the control simulation. Lower (higher) $\mathrm{O}_{\mathrm{x}}$ concentration results in more (less) assembled ozone and hence increased (decreased) $D_{\mathrm{O}_{3}}$.

In summary, all model simulations with altered initial concentrations indicate that $D_{\mathrm{O}_{3}}$ is anti-correlated to changes in $\mathrm{O}_{\mathrm{x}}$ and $\mathrm{NO}_{\mathrm{y}}$ at $5 \mathrm{hPa}$. Considering that all loss terms in Eq. (9) are linear in ozone and $\mathrm{O}_{x}$ is mostly $\mathrm{O}_{3}$, this is an understandable behaviour. Based on these promising simu-

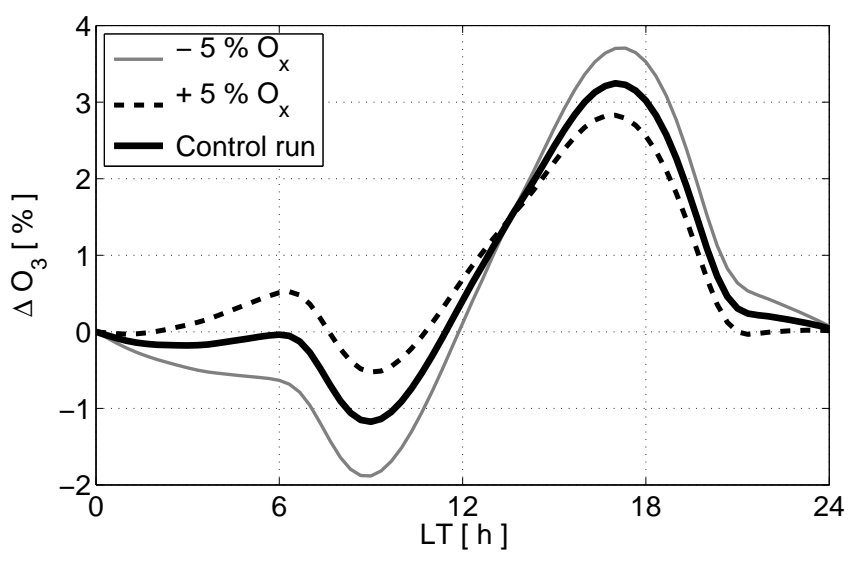

Figure 12. Daily ozone cycles derived from simulations with $\pm 5 \%$ initial $\mathrm{O}_{\mathrm{x}}$ concentration and a control simulation shown for 1 January, $5 \mathrm{hPa}, 22^{\circ} \mathrm{N}$.

lation results, we assumed that an anti-correlation of $D_{\mathrm{O}_{3}}$ to $\mathrm{O}_{\mathrm{x}}$ and $\mathrm{NO}_{\mathrm{y}}$ also induces regional effects in the daily ozone cycle (comparable to Fig. 7a and d but not shown here).

We remark that the initial conditions of atmospheric fields were altered under no consideration of the correct partitioning of the day and night side of the Earth. The initial trace gases were altered simultaneously on 1 January, 00:00 UT at all points of the model grid. Since $\mathrm{O}_{x}$ is mostly $\mathrm{O}_{3}$ at $5 \mathrm{hPa}$ and we preserved the $\mathrm{NO}_{\mathrm{x}} / \mathrm{NO}_{\mathrm{y}}$ concentration ratio, potential bias in our simulation is considered to play a minor role.

Regional variations of atmospheric trace gases are described by anomalies as defined in Eq. (5). The regional anomalies in $\mathrm{NO}$ and $\mathrm{O}_{3}$ are of synoptic scale in the WACCM simulation. From tropical to middle latitudes these anomalies vary up to approximately $\pm 10 \%$. In Fig. 13 we relate anomalies in $\mathrm{NO}_{\text {noon }}\left(\mathrm{NO}\right.$ at 12:00 LT) and $\mathrm{O}_{3}$, mid $\left(\mathrm{O}_{3}\right.$ at 24:00 LT) to anomalies in $D_{\mathrm{O}_{3}}$ for March, June, September and December. The data used in Fig. 13 are taken for the latitude range $\lambda \pm 30^{\circ}$ where $\lambda_{\text {sub }}$ is the subsolar latitude. Figure 13 shows that $D_{\mathrm{O}_{3}}$ is often anti-correlated to anomalies in $\mathrm{NO}_{\text {noon }}$ and $\mathrm{O}_{3}$, mid. $D_{\mathrm{O}_{3}}$ decreases from positive (red) to negative values (blue) when the anomalies $\mathrm{NO}^{\prime}$ and $\mathrm{O}_{3}^{\prime}$ increase from negative to positive values.

We find further effects at high latitude related to atmospheric composition. A strong effect based on the anticorrelation of anomalies in $\mathrm{O}_{3}$ and $D_{\mathrm{O}_{3}}$ occurs in the Pacific region in December (Fig. 7d, Region C), where an ozone anomaly of approximately $-10 \%$ leads to strong increases of $D_{\mathrm{O}_{3}}$ over a wide region. Nevertheless, the anti-correlation of $\mathrm{NO}$ and $D_{\mathrm{O}_{3}}$ remains weak due to the complex partitioning of the $\mathrm{NO}_{\mathrm{y}}$ family. Based on the reservoir coupling, some of the reactive $\mathrm{NO}$ is in the form of $\mathrm{N}_{2} \mathrm{O}_{5}$ during the diurnal $\mathrm{NO}_{\mathrm{x}}$ cycle (Walker and Dudhia, 2011). Owing to this fact, Fig. 14 gives an overview of distributions of $\mathrm{NO}, \mathrm{NO}_{2}$ and $\mathrm{N}_{2} \mathrm{O}_{5}$, showing the day- and night-time partitioning at $5 \mathrm{hPa}$. The $\mathrm{NO}_{\mathrm{y}}$ partitioning as simulated by WACCM qualitatively 


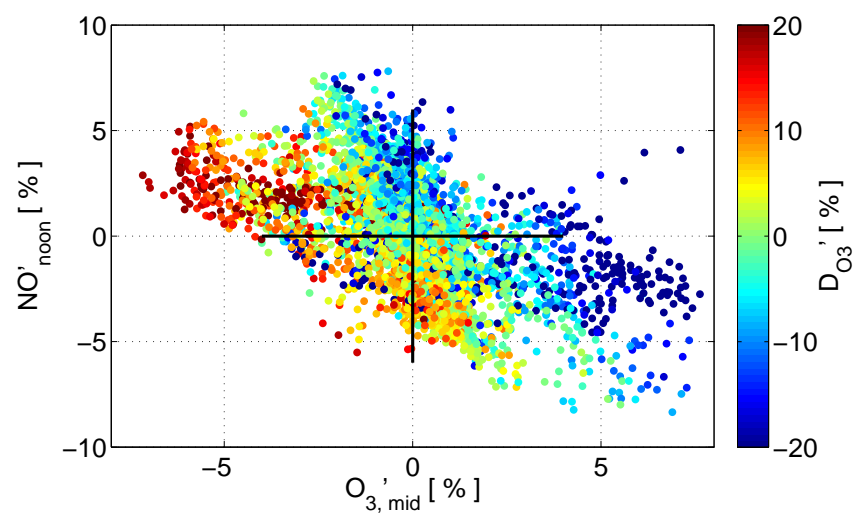

Figure 13. Dependence of $D_{\mathrm{O}_{3}}$ anomalies on anomalies in $\mathrm{NO}_{\text {noon }}$ (NO at 12:00 LT) and $\mathrm{O}_{3}$, mid $\left(\mathrm{O}_{3}\right.$ at 24:00 LT) for monthly means of March, June, September and December. Data points are taken from $\lambda_{\text {sub }} \pm 30^{\circ}$, where $\lambda_{\text {sub }}$ is the subsolar latitude. Two anti-correlations appear: increased (decreased) $\mathrm{NO}_{\text {noon }}$ or $\mathrm{O}_{3}$, mid mostly lead to decreasing (increasing) $D_{\mathrm{O}_{3}}$.

agrees with satellite observations of MIPAS (Michelson Interferometer for Passive Atmospheric Sounding) (Funke and López-Puertas, 2005; Fischer et al., 2008). However, it is difficult to give a comprehensive view of anomalies in reactive $\mathrm{NO}_{\mathrm{x}}$ since it is never in a state of equilibrium with the reservoir $\mathrm{N}_{2} \mathrm{O}_{5}$ (Brasseur and Solomon, 2005).

Aside from anomalies, the amounts of $\mathrm{NO}, \mathrm{NO}_{2}$ and $\mathrm{N}_{2} \mathrm{O}_{5}$ shown in Fig. 14 are conspicuously low at the equator. Poleward-drifting branches of the Brewer-Dobson circulation (Brewer, 1948) may explain the equatorial anomaly in Fig. 14. This might by an example of how dynamics come into play and calls for three-dimensional chemistryclimate models to assess the daily ozone cycle.

\subsection{Zonal wind-induced effects on $D_{\mathrm{O}_{3}}$}

In the stratosphere, westerly and easterly winds of up to $100 \mathrm{~m} \mathrm{~s}^{-1}$ occur. Due to the apparent move of the Sun from the east to the west, the sunshine duration of an air parcel decreases for westerly winds and increases for easterly winds. The photochemical system will response to these changes with an altered daily cycle of ozone. The effect is more pronounced at high latitudes, since the Earth's rotation velocity decreases at higher latitudes $(v=\Omega a \cos (\lambda)$, with $a$ : Earth radius; $\Omega$ : Earth angular velocity; $\lambda$ : latitude). Sonnemann (2001) formulated the zonal wind-dependence of the sunshine duration of an air parcel by means of the well-known Doppler effect. Numerical simulations showed that the quasiperiodic radiative forcing can induce photochemical oscillations of mesospheric trace gases (DopplerSonnemann effect).

For a rough estimate, we consider an easterly wind with $30 \mathrm{~m} \mathrm{~s}^{-1}$ over a period of $7 \mathrm{~h}$ during daytime with regard to a change in sunshine duration. The enhancement of sunshine duration is approximately $7.5 \%$ at $60^{\circ}$ latitude and $3.8 \%$ at the equator for an easterly wind. A westerly wind will have the opposing effect, i.e. a reduction of sunshine duration. This significant change in sunshine duration manifests itself in a regional modulation of the daily ozone cycle. Regions with strong westerly winds tend to show weaker $D_{\mathrm{O}_{3}}$, whereas regions with easterly winds tend to show enhanced $D_{\mathrm{O}_{3}}$.

For instance, in Fig. 7d strong westerly winds at high latitudes can be found from the east coast of North America to central Siberia (Region D). These zonal winds correlate to regionally damped $D_{\mathrm{O}_{3}}(0.08 \mathrm{ppmv}, 1.3 \%)$.

\subsection{Other potential sources of regional $D_{\mathrm{O}_{3}}$ variability}

The previous discussion did not consider regional variations of the actinic radiation in the stratosphere as induced by changes in cloud coverage, aerosol distribution, surface albedo and greenhouse gases (Meier et al., 1997). We expect many effects on the daily cycle of stratospheric ozone and other parameters. Further, it is well-known that turbulence and gravity wave flux have strong daily cycles which may effect the regional, seasonal and global behaviour of the daily ozone cycle. It is beyond the scope of the present study to investigate all effects. However, the WACCM simulations seem to be appropriate for advanced studies of the details of the daily ozone cycle.

Finally, it is desirable to link these results to satellite-based ozone trend analysis. In particular, corrections due to atmospheric constituents such as $\mathrm{O}_{3}$ and $\mathrm{NO}$ and stratospheric temperature variations are challenging. In addition, the spatiotemporal variability of thermal tides in the upper stratosphere may induce a variability in the daily ozone cycle.

\section{Conclusions}

We gave a comprehensive overview of the global, seasonal and regional behaviour of the daily ozone cycle in the stratosphere at $5 \mathrm{hPa}$, modelled with the fully coupled chemistryclimate model WACCM. The daily cycle of stratospheric ozone is strongest at about $5 \mathrm{hPa}$ where the peak-to-valley difference is approximately $3-5 \%(0.4 \mathrm{ppmv})$ for midlatitudes and tropics. However, during polar summer at high latitudes $\left(66.6^{\circ}\right.$ lat) the daily ozone cycle can be up to $15 \%$ $(0.8 \mathrm{ppmv})$. Satellite-derived trend estimates of stratospheric ozone are certainly biased by the daily ozone cycle since the ozone trends are of the order of a few percent per decade and the satellite orbits are shifted in local time. Additionally, each satellite orbit slowly drifts away from its initial orbit during the years in operation. For a future correction of the diurnal biases in stratospheric ozone trend estimates it is important to derive the characteristics of the daily ozone cycle, to validate the characteristics and to understand the fundamental processes which are causing the daily ozone cycle. 

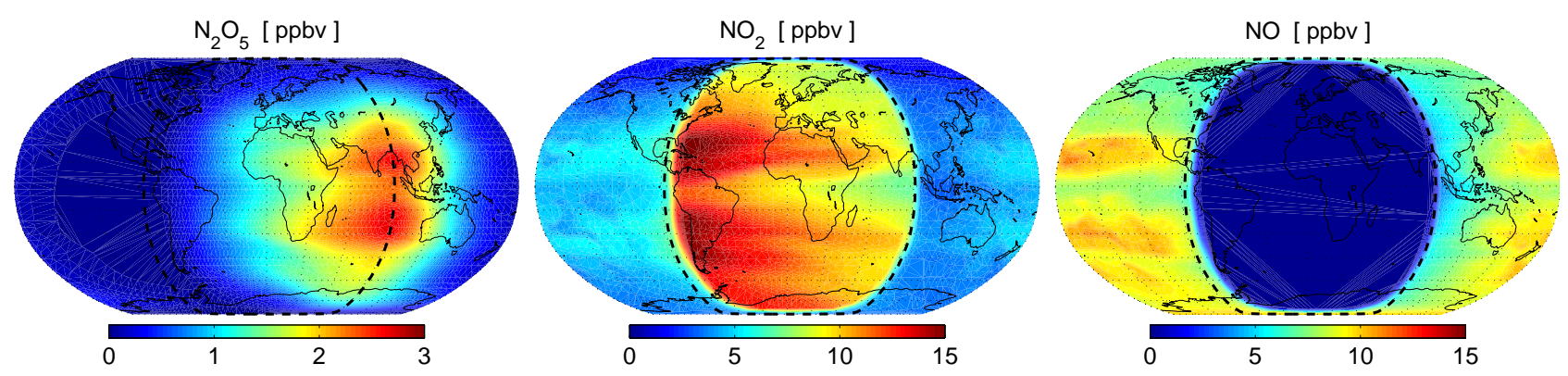

Figure 14. Snapshot of $\mathrm{N}_{2} \mathrm{O}_{5}, \mathrm{NO}_{2}$ and $\mathrm{NO}$ as simulated by WACCM at $5 \mathrm{hPa}, 21 \mathrm{March}, 00: 00 \mathrm{UT}$. The solar zenith angle of $90^{\circ}$ (dashed black lines) approximately marks the solar terminator. The nightside is at the centre of the maps. The reservoir $\mathrm{N}_{2} \mathrm{O}_{5}$ is assembled during night-time by Reaction (R12) until it peaks at the solar terminator. During daytime $\mathrm{N}_{2} \mathrm{O}_{5}$ is dissociated into $\mathrm{NO}_{2}$ and $\mathrm{NO}_{3}$ by $\mathrm{Reactions}(\mathrm{R} 14)$ and (R13). $\mathrm{NO}_{2}$ in turn is photodissociated into $\mathrm{NO}$ and $\mathrm{O}$ or reacts with $\mathrm{O}$ by Reactions (R9) and (R10). Both reactions provide reactive $\mathrm{NO}$ which plays a major role in the daily ozone cycle at $5 \mathrm{hPa}$.

The present study shows that the global view of WACCM on the daily ozone cycle is invaluable for understanding and planning a correction method.

Generally, the results of WACCM are in good agreement with previously reported results of photochemical box models at northern midlatitudes (Herman, 1979; Fabian et al., 1982; Pallister and Tuck, 1983). WACCM and the box models show a daily cycle of stratospheric ozone with a $1 \%$ decrease after sunrise and a slow ascent to approximately 3-5\% in the late afternoon (similar to Fig. 2). Thus, it seems that WACCM should be quite reliable with regard to information about the daily ozone cycle at any region. In addition, we find the daily ozone cycle of WACCM in good agreement with observations by a microwave radiometer at Bern, Switzerland (Studer et al., 2014), which operates as part of the frame of NDACC and with satellite-based observations of SMILES (Sakazaki et al., 2013) and TIMED or SABER (Huang et al., 2008). The surprising strong daily ozone cycle at high latitudes in polar summer is confirmed by observations of a ground-based microwave radiometer at Ny-Ålesund, Svalbard (Palm et al., 2013). The simulation and observational result is of high importance for future trend studies of polar stratospheric ozone which is most disturbed, variable and difficult for models to project the expected recovery phase of the stratospheric ozone layer.

Comparing characteristics of the daily ozone cycle from our own model data and other relevant literature, we note one remarkable difference: WACCM and the photochemical box models show a decrease of stratospheric ozone after sunrise, while ground-based radiometers measure more or less constant values of stratospheric ozone after sunrise at midlatitudes. The disagreement could be due to an observation error, a retrieval error or a simulation error. This example shows how the daily ozone cycle could be utilised as a test signal for controlling and improving measurement and retrieval techniques as well as for quality assessment of atmospheric composition, photochemistry and dynamics in chemistry-climate models.
Our simulations show manifold variations in the daily ozone cycle at $5 \mathrm{hPa}$. Though the simple statement that the daily cycle of stratospheric ozone mainly depends on ozone photochemistry is true, ozone photochemistry itself depends on solar zenith angle, sunshine duration, temperature, zonal wind, ozone concentration and ozone-depleting substances such as $\mathrm{NO}_{\mathrm{x}}$ and $\mathrm{Cl}_{\mathrm{x}}$. All of them together are responsible for the global, seasonal and regional characteristics of the daily ozone cycle presented in the entirety of our figures. By means of the model, it was partly possible to disentangle the different effects or to learn about their interconnections. For example, we find that temperature tides with amplitudes of approximately $1 \mathrm{~K}$ can lead to a reduction of $2 \%$ in the strength of the daily ozone cycle. The high spatiotemporal variability of temperature tides could be a major hurdle for a future correction of diurnal biases in trend estimates of stratospheric ozone. Extensive simulations by chemistryclimate models could allow a realistic estimation of the diurnal biases in satellite-derived trend estimates of stratospheric ozone.

In the polar region in winter, our simulation showed diurnal ozone variation which we related to advection at diurnal and shorter timescales. We suggest that these advection processes at the polar vortex and the associated diurnal ozone variations might be stronger in the real atmosphere since the low-resolution, free-running WACCM simulation underestimates the influence of gravity waves on middle atmospheric dynamics (Richter et al., 2008). Therefore, a realistic representation of middle atmospheric advection at shorter timescales seems to overstress the prospects of the free-running WACCM model. Sato et al. (2009) showed that high-resolution modelling at $60 \mathrm{~km}$ horizontal and $300 \mathrm{~m}$ vertical resolution internally generates realistic propagation and momentum deposition of gravity waves without any gravity wave parametrisation. Further research on advection in the polar region in winter could be based on data from such highresolution modelling or from data assimilation systems with well-reflected dynamics at diurnal and shorter timescales. 
Our results may also help to understand the daily ozone cycle at different altitudes. For instance, in the upper stratosphere we assume a growing influence on ozone photochemistry from the $\mathrm{HO}_{\mathrm{x}}$ and $\mathrm{Cl}_{\mathrm{x}}$ cycles. From observations it is known that the behaviour of the daily ozone cycle is different at other altitudes (Haefele et al., 2008; Studer et al., 2014). A comprehensive understanding can be achieved by further analysis of chemistry-climate simulation data.
In summary, we conclude that a correction of the diurnal biases in stratospheric ozone series is more difficult than expected (e.g. regional anomalies, temperature tides) and more necessary than expected (e.g. strong daily cycle of polar summer ozone). Further work on this research topic by observers and modellers may lead, step-by-step, to a reliable correction of diurnal biases of ozone series. As a spin-off, we expect progress in modelling, instrument and retrieval techniques. 


\section{Appendix A: Definitions of reaction rates}

Definitions of missing reaction coefficients of Eq. (9). The dagger symbol $\left(^{\dagger}\right)$ denotes vibrationally excited molecules.

$\left(b_{4}\right) ; \mathrm{NO}+\mathrm{O}_{3} \rightarrow \mathrm{NO}_{2}+\mathrm{O}_{2}$

$\left(b_{9}\right) ; \mathrm{NO}_{2}+\mathrm{O}_{3} \rightarrow \mathrm{NO}_{3}+\mathrm{O}_{2}$

$\left(a_{2}\right) ; \mathrm{H}+\mathrm{O}_{3} \rightarrow \mathrm{O}_{2}+\mathrm{OH}^{\dagger}$

$\left(a_{6}\right) ; \mathrm{OH}+\mathrm{O}_{3} \rightarrow \mathrm{NO}+\mathrm{NO}_{2}$

$\left(a_{6 b}\right) ; \mathrm{HO}_{2}+\mathrm{O}_{3} \rightarrow \mathrm{OH}+2 \mathrm{O}_{2}$

$\left(d_{2}\right) ; \mathrm{Cl}+\mathrm{O}_{3} \rightarrow \mathrm{ClO}+\mathrm{O}_{2}$

$\left(e_{2}\right) ; \mathrm{Br}+\mathrm{O}_{3} \rightarrow \mathrm{BrO}+\mathrm{O}_{2}$ 
Acknowledgements. The research leading to these results has received funding from the European Community's Seventh Framework Programme ([FP7/2007-2013]) under grant agreement no. 284421 (see Article II.30. of the Grant Agreement). Also we would like to acknowledge the International Space Science Institute, Bern, Switzerland (ISSI Team \#246, Characterizing Diurnal Variations of Ozone for Improving Ozone Trend Estimates, http://www.issibern.ch/teams/ozonetrend/) and the Ubuntu Foundation for providing open source software.

Edited by: P. Jöckel

\section{References}

Aimedieu, P., Rigaud, P., and Barat, J.: The sunrise depletion problem of the upper stratosphere, Geophys. Res. Lett., 8, 787-789, 1981.

Barth, C. A., Rusch, D. W., Thomas, R. J., Mount, G. H., Rottman, G. J., Thomas, G. E., Sanders, R. W., and Lawrence, G. M.: Solar mesosphere explorer: Scientific objectives and results, Geophys. Res. Lett., 10, 237-240, doi:10.1029/GL010i004p00237, 1983.

Bates, D. R. and Nicolet, M.: The photochemistry of atmospheric water vapor, J. Geophys. Res., 55, 3, 301-327, doi:10.1029/JZ055i003p00301, 1950.

Bhartia, P. K., McPeters, R. D., Flynn, L. E., Taylor, S., Kramarova, N. A., Frith, S., Fisher, B., and DeLand, M.: Solar Backscatter UV (SBUV) total ozone and profile algorithm, Atmos. Meas. Tech., 6, 2533-2548, doi:10.5194/amt-6-2533-2013, 2013.

Brasseur, G. P. and Solomon, S.: Aeronomy of the middle Atmosphere, Springer, Atmospheric and Oceanographic Science Library, Springer Dordrecht, Netherlands, 2005.

Brewer, A. W.: Evidence for a world circulation provided by the measurement of helium and water vapour distribution in the stratosphere, Q. J. Roy. Meteor. Soc., 75, 351-363, doi:10.1002/qj.49707532603, 1949.

Chapman, S.: A theory of upper atmosphere ozone, Mem. R. Metrol. Soc., 3, 103-125, 1930.

Chehade, W., Weber, M., and Burrows, J. P.: Total ozone trends and variability during 1979-2012 from merged data sets of various satellites, Atmos. Chem. Phys., 14, 7059-7074, doi:10.5194/acp14-7059-2014, 2014

Chubachi, S.: A special ozone observation at Syowa station, Antarctica from February 1982 to January 1983, P. Soc. Photo.-Opt. Ins., 285-289, doi:10.1007/978-94-009-5313-0_58, 1985.

Connor, B. J., Siskind, D. E., Tsou, J. J., Parrish, A., and Remsberg, E. E.: Ground-based microwave observations of ozone in the upper stratosphere and mesosphere, J. Geophys. Res., 99, 16757-16770, doi:10.1029/94JD01153, 1994.

Craig, R. A. and Ohring, G.: The temperature dependence of ozone radiational heating rates in the vicinity of the mesopeak, J. Meteorol., 15, 59-62, doi:10.1175/15200469(1958)015<0059:TTDOOR>2.0.CO;2, 1957.

Crutzen, P. J.: The influence of nitrogen oxides on the atmospheric ozone content, Q. J. Roy. Meteor. Soc., 96, 320-325, doi:10.1126/science.189.4201.457, 1970.
DeLand, M. T., Taylor, S. L., Huang, L. K., and Fisher, B. L.: Calibration of the SBUV version 8.6 ozone data product, Atmos. Meas. Tech., 5, 2951-2967, doi:10.5194/amt-5-2951-2012, 2012.

Emmons, L. K., Walters, S., Hess, P. G., Lamarque, J.-F., Pfister, G. G., Fillmore, D., Granier, C., Guenther, A., Kinnison, D., Laepple, T., Orlando, J., Tie, X., Tyndall, G., Wiedinmyer, C., Baughcum, S. L., and Kloster, S.: Description and evaluation of the Model for Ozone and Related chemical Tracers, version 4 (MOZART-4), Geosci. Model Dev., 3, 43-67, doi:10.5194/gmd3-43-2010, 2010.

Eyring, V., Waugh, D., W., Bodeker, G. E., Cordero, E., Akiyoshi, H., Austin, J., Beagley, S. R., Boville, B. A., Braesicke, P., Brühl, C., Butchart, N., Chipperfield, M. P., Dameris, M., Deckert, R., Deushi, M., Frith, S. M., Garcia, R. R., Gettelman, A., Giorgetta, M. A., Kinnision, D. E., Mancini, E., Manzini, E., Marsh, D. R., Matthes, S., Nagashima, T., Newman, P. A., Nielson, J. E., Pawson, S., Pitari, G., Plummer, D. A., Rozanov, E., Schraner, M., Scinocca, J. F., Semeniuk, K., Shepherd, T. G., Shibata, K., Steil, B., Stolarski, R. S., Tian, W., and Yoshiki, M.: Multimodel projections of stratospheric ozone in the 21st century, J. Geophys. Res., 112, D16303, doi:10.1029/2006JD008332, 2007.

Fabian, P., Pyle, J. A., and Wells, R. J.: Diurnal variations of minor constituents in the stratosphere modeled as a function of latitude and season, J. Geophys. Res., 87, 4981-5000, doi:10.1029/JC087iC07p04981, 1982.

Farman, J. C., Gardiner, B. G., and Shanklin, J. D.: Large losses of total ozone in Antarctica reveal seasonal $\mathrm{ClO}_{\mathrm{x}} / \mathrm{NO}_{\mathrm{x}}$ interaction, Nature, 315, 207-210, doi:10.1038/315207a0, 1985.

Fischer, H., Birk, M., Blom, C., Carli, B., Carlotti, M., von Clarmann, T., Delbouille, L., Dudhia, A., Ehhalt, D., Endemann, M., Flaud, J. M., Gessner, R., Kleinert, A., Koopmann, R., Langen, J., López-Puertas, M., Mosner, P., Nett, H., Oelhaf, H., Perron, G., Remedios, J., Ridolfi, M., Stiller, G., and Zander, R.: MIPAS: an instrument for atmospheric and climate research, Atmos. Chem. Phys., 9, 2151-2188, doi:10.5194/acp-8-2151-2008, 2008.

Froidevaux, L., Allen, M., Berman, S., and Daughton, A.: The mean ozone profile and its temperature sensitivity in the upper stratosphere and lower mesosphere: an analysis of LIMS observations, J. Geophys. Res., 94, 6389-6417, doi:10.1029/JD094iD05p06389, 1998.

Funke, B., López-Puertas, M., von Clarmann, T., Stiller, G., Fischer, H., Glatthor, N., Grabowski, U., Höpfner, M., Kellmann, S., Kiefer, M., Linden, A., Mengistu Tsidu, G., Milz, M., Steck, T., and Wang, D.,Y.: Retrieval of stratospheric $\mathrm{NO}_{\mathrm{x}}$ from 5.3 and $6.2 \mu \mathrm{m}$ nonlocal thermodynamic equilibrium emissions measured by Michealson Interferometer for Passive Atmospheric Sounding (MIPAS) on Envisat, J. Geophys. Res., 110, D09302, doi:10.1029/2004JD005225, 2005.

Garcia, R. R., Marsh, D. R., Kinnison, D. E., Boville, B. A., and Sassi, F.: Simulation of secular trends in the middle atmosphere, 1950-2003, J. Geophys. Res., 112, D09301, doi:10.1029/2006JD007485, 2007.

Garny, H., Bodeker, G. E., Smale, D., Dameris, M., and Grewe, V.: Drivers of hemispheric differences in return dates of mid-latitude stratospheric ozone to historical levels, Atmos. Chem. Phys., 13, 7279-7300, doi:10.5194/acp-13-7279-2013, 2013. 
Gebhardt, C., Rozanov, A., Hommel, R., Weber, M., Bovensmann, H., Burrows, J. P., Degenstein, D., Froidevaux, L. and Thompson, A. M.:, Stratospheric ozone trends and variability as seen by SCIAMACHY from 2002 to 2012, Atmos. Chem. Phys, 14, 2, 831-846, doi:10.5194/acp-14-831-2014, 2014.

Haefele, A., Hocke, K., Kämpfer, N., Keckhut, P., Marchand, M., Bekki, S., Morel, B., Egorova, T., and Rozanov, E.: Diurnal changes in middle atmospheric $\mathrm{H}_{2} \mathrm{O}$ and $\mathrm{O}_{3}$ : observations in the alpine region and climate models, J. Geophys. Res., 113, D17303, doi:10.1029/2008JD009892, 2008.

Herman, J. R.: The response of stratospheric constituents to a solar eclipse, sunrise, and sunset, J. Geophys. Res., 84, 3701-3710, doi:10.1029/JC084iC07p03701, 1979.

Huang, F. T., Mayr, H. G., Russell Ill, J. M., Mlynczak, M. G., Reber, C. A.: Ozone diurnal variations and mean profiles in the mesosphere, lower thermosphere, and stratosphere, based on measurements from SABER on TIMED, J. Geophys. Res., 113, A4307, doi:10.1029/2007JA012739, 2008.

Huang, F. T., McPeters, R. D., Bhartia, P. K., Mayr, H. G., Frith, S. M., Russell Ill, J. M., and Mlynczak, M. G.: Temperature diurnal variations (migrating tides) in the stratosphere and lower mesosphere based on measurements from SABER on TIMED, J. Geophys. Res., 115, D161121, doi:10.1029/2009JD013698, 2010.

Johnston, H.: Reduction of stratospheric ozone by nitrogen oxide catalysts from supersonic transport exhaust, Science, 173, 517522, doi:10.1126/science.173.3996.517, 1971.

Johnston, H. S. and Podolske, J.: Interpretation of stratospheric photochemistry, Rev. Geophys. Space Ge., 16, 491-519, doi:10.1029/RG016i004p00491, 1978.

Jonsson, A. I, Fomichev, V. I., and Sheperd, T. G.: The effect of nonlinearity in $\mathrm{CO}_{2}$ heating rates on the attribution of stratospheric ozone and temperature changes, Atmos. Chem. Phys., 9, 84478452, doi:10.5194/acp-9-8447-2009, 2009.

Khosravi, M., Baron, P., Urban, J., Froidevaux, L., Jonsson, A. I., Kasai, Y., Kuribayashi, K., Mitsuda, C., Murtagh, D. P., Sagawa, H., Santee, M. L., Sato, T. O., Shiotani, M., Suzuki, M., von Clarmann, T., Walker, K. A., and Wang, S.: Diurnal variation of stratospheric and lower mesospheric $\mathrm{HOCl}, \mathrm{ClO}$ and $\mathrm{HO}_{2}$ at the equator: comparison of 1-D model calculations with measurements by satellite instruments, Atmos. Chem. Phys., 13, 7587-7606, doi:10.5194/acp-13-7587-2013, 2013.

Kikuchi, K., Nishibori, T., Ochiai, S., Ozeki, H., Irimajiri, Y., Kasai, Y., Koike, M., Manabe, T., Mizukoshi, K., Murayama, Y., Nagahama, T., Sano, T., Sato, R., Seta, M., Takahashi, C., Takayanagi, M., Masuko, H., Inatani, J., Suzuki, M., and Shiotani, M.: Overview and early results of the Superconducting Submillimeter-Wave Limb-Emission Sounder (SMILES), J. Geophys. Res., 115, D23306, doi:10.1029/2010JD014379, 2013.

Kinnison, D. E., Brasseur, G. P., Walters, S., Garcia, R. R., Marsh, D. R., Sassi, F., Harvey, V. L., Randall, C. E., Emmons, L., Lamarque, J. F., Hess, P., Orlando, J. J., Tie, X. X., Randel, W., Pan, L. L., Gettelman, A., Granier, C., Diehl, T., Niemeier, U., and Simmons, A. J.: Sensitivity of chemical tracers to meteorological parameters in the MOZART-3 chemical transport model, J. Geophys. Res., 112, D20302, doi:10.1029/2006JD007879, 2007.

Kuribayashi, K., Sagawa, H., Lehmann, R., Sato, T. O., and Kasai, Y.: Direct estimation of the rate constant of the reaction
$\mathrm{ClO}+\mathrm{HO}_{2} \rightarrow \mathrm{HOCl}+\mathrm{O}_{2}$ from SMILES atmospheric observations, Atmos. Chem. Phys., 14, 255-266, doi:10.5194/acp-14255-2014, 2014.

Kyrölä, E., Laine, M., Sofieva, V., Tamminen, J., Päivärinta, S.-M., Tukiainen, S., Zawodny, J. and Thomason, L.: Combined SAGE II-GOMOS ozone profile data set for 1984-2011 and trend analysis of the vertical distribution of ozone, Atmos. Chem. Phys., 13, 21, 10645-10658, doi:10.5194/acp-13-10645-2013, 2013.

Lean, J. L.: Observation of the diurnal variation of atmospheric ozone, J. Geophys. Res., 87, 4973-4980, doi:10.1029/JC087iC07p04973, 1982.

Marsh, D. R., Garcia, R. R., Kinnison, D. E., Boville, B. A., Walters, S., Matthes, K., and Solomon, S. C.: Modeling the whole atmosphere response to solar cycle changes in radiative and geomagnetic forcing, J. Geophys. Res., 112, D23306, doi:10.1029/2006JD008306, 2007.

McElroy, M. B. Salawitch, R. J., Wofsy, S. C., and Logan, J. A.: Reductions of Antarctic ozone due to synergistic interactions of chlorine and bromine, Nature, 321, 759-762, doi:10.1038/321759a0, 1986.

McPeters, R. D., Miles, T., Flynn, L. E., Wellemeyer, C. G., and Zawodny, J. M.: Comparison of SBUV and SAGE II ozone profiles: implications for ozone trends, J. Geophys. Res., 99, 20513 20524, doi:10.1029/94JD02008, 1994.

Meier, R. R., Anderson, G. P., Cantrell, C. A., Hall, L. A., Lean, J., Minschwaner, K., Shetter, R. E., Shettle, E. P., and Stamnes, K.: Actinic radiation in the terrestrial atmosphere, J. Atmos. Sol.Terr. Phy., 59, 2111-2157, doi:10.1016/S1364-6826(97)000473, 1997.

Molina, M. J. and Rowland, F. S.: Stratospheric sink for chlorofluoromethanes: chlorine atom-catalysed destruction of ozone, Nature, 249, 810-812, doi:10.1038/249810a0, 1974.

Muncaster, R., Bourqui, M. S., Chabrillat, S., Viscardy, S., Melo, S. M. L., and Charbonneau, P.: A simple framework for modelling the photochemical response to solar spectral irradiance variability in the stratosphere, Atmos. Chem. Phys., 12, 7707-7724, doi:10.5194/acp-12-7707-2012, 2012.

Nicolet, M.: Stratospheric ozone: an introduction to its study, Rev. Geophys. Space Ge., 13, 593-636, doi:10.1029/RG013i005p00593, 1975.

Pallister, R. C. and Tuck, A. F.: The diurnal variation of ozone in the upper stratosphere as a test of photochemical theory, Q. J. Roy. Meteor. Soc., 109, 271-284, doi:10.1002/qj.49710946002, 1983.

Palm, M., Golchert, S. H. W., Sinnhuber, M., Hochschild, G., and Notholt, J.: Influence of Solar Radiation on the Diurnal and Seasonal Variability of $\mathrm{O}_{3}$ and $\mathrm{H}_{2} \mathrm{O}$ in the Stratosphere and Lower Mesosphere, Based on Continuous Observations in the Tropics and the High Arctic, Springer Atmospheric Sciences, 125-147, doi:10.1007/978-94-007-4348-9_8, Springer Dordrecht Heidelberg New York London, 2013.

Phillips, N. A.: A coordinate system having some special advantages for numerical forecasting, J. Meteorol., 14, 184-185, 1957.

Ravishankara, A. R., Daniel, J. S., and Portmann, R. W.: Nitrous oxide $\left(\mathrm{N}_{2} \mathrm{O}\right)$ : the dominant ozone-depleting substance emitted in the 21st century, Science, 326, 123-125, doi:10.1126/science.1176985, 2009.

Revell, L. E., Bodeker, G. E., Huck, P. E., Williamson, B. E., and Rozanov, E.: The sensitivity of stratospheric ozone changes 
through the 21st century to $\mathrm{N}_{2} \mathrm{O}$ and $\mathrm{CH}_{4}$, Atmos. Chem. Phys., 12, 11309-11317, doi:10.5194/acp-12-11309-2012, 2012.

Richter, J. H., Sassi, F., Garcia, R. R., Matthes, K., and Fischer, C. A.: Dynamics of the middle atmosphere as simulated by the Whole Atmosphere Community Climate Model, version 3 (WACCM3), J. Geophys. Res., 113, D08101, doi:10.1029/2007JD009269, 2008

Russell III, J. M., Mlynczak, M. G., Gordley, L. L., Tansock Jr., J. J., and Esplin, R. W.:"Overview of the SABER experiment and preliminary calibration results", Proc. SPIE 3756, Optical Spectroscopic Techniques and Instrumentation for Atmospheric and Space Research III, 277 (October 20, 1999); doi:10.1117/12.366382, 1999.

Sakazaki, T., Fujiwara, M., Zhang, X., Hagan, M. E., and Forbes, J. M.: Diurnal tides from the troposphere to the lower mesosphere as deduced from TIMED/SABER satellite data and six global reanalysis data sets, J. Geophys. Res., 117, D13108, doi:10.1029/2011JD017117, 2012.

Sakazaki, T., Fujiwara, M., Mitsuda, C., Imai, K., Manago, N., Naito, Y., Nakamura, T., Akiyoshi, H., Kinnison, D., Sano, T., Suzuki, M., and Shiotani, M.: Diurnal ozone variations in the stratosphere revealed in observations from the Superconducting Submillimeter-Wave Limb-Emission Sounder (SMILES) on board the International Space Station (ISS), J. Geophys. Res., 118, 1-16, doi:10.1002/jgrd.50220, 2013.

Sander, S. P., Friedl, R. R., Abbatt, J. P. D., Barker, J. R., Burkholder, J. B., Golden, D. M., Kolb, C. E., Kurylo, M. J., Moortgart, G. K., Wine, P. H., Huie, R. E., and Orkin, V. L.: Chemical Kinetics and Photochemical Data for Use in Atmospheric Studies, JPL Publ., 10-6, 17, 2011.

Sarma, K. M. and Bankobeza, G. M.: The Montreal protocol on substances that deplete the ozone layer, United Nations Environment Programme, Nairobi, Kenya, 2000.

Sato, K., Watanabe, S., Kawatani, Y., Tomikawa, Y., Miyazaki, K., and Takahashi, M.: On the origin of mesospheric gravity waves, Geophys. Res. Lett., 36, L19801, doi:10.1029/2009GL039908, 2009.

Shindell, D. T., Rind, D., and Lonergan, P.: Increased polar stratospheric ozone losses and delayed eventual recovery owing to increasing greenhouse-gas concentrations, Nature, 392, 589-592, doi:10.1038/33385, 1998.
Solomon, S. and Garcia, R. R.: On the distributions of long-lived tracers and chlorine species in the middle atmosphere, J. Geophys. Res., 89, 11633-11644, doi:10.1029/JD089iD07p11633, 1984.

Sonnemann, G. R.: The photochemical effects of dynamically induced variations in solar insolation, J. Atmos. Sol.-Terr. Phy., 63, 781-797, doi:10.1016/S1364-6826(01)00010-4, 2001.

SPARC CCMV: SPARC Report on the evaluation of ChemistryClimate, edited by: Models, V., Eyring, V., Sheperd, T. G., and Waughn, D. W., SPARC Report No. 5, WRCP-132, WMO/TDNo.1526, 2010.

Stolarski, R. S. and Cicerone, R. J.: Stratospheric chlorine: a possible sink for ozone, Can. J. Chem., 52, 1610-1615, doi:10.1139/v74-233, 1974.

Stolarski, R. S. and Frith, S. M.: Search for evidence of trend slowdown in the long-term TOMS/SBUV total ozone data record: the importance of instrument drift uncertainty, Atmos. Chem. Phys., 6, 4057-4065, doi:10.5194/acp-6-4057-2006, 2006.

Studer, S., Hocke, K., Schanz, A., Schmidt, H., and Kämpfer, N.: A climatology of the diurnal variations in stratospheric and mesospheric ozone over Bern, Switzerland, Atmos. Chem. Phys., 14, 5905-5919, doi:10.5194/acp-14-5905-2014, 2014.

Tilmes, S., Kinnison, D. E., Garcia, R. R., Müller, R., Sassi, F., Marsh, D. R., and Boville, B. A.: Evaluation of heterogeneous processes in the polar lower stratosphere in the Whole Atmosphere Community Climate Model, J. Geophys. Res., 112, D24301, doi:10.1029/2006JD008334, 2007.

Tung, K. K., Ko, M. K. W., Rodriguez, J. M., and Sze, N. D.: Are Antarctic ozone variations a manifestation of dynamics or chemistry?, Nature, 322, 811-814, doi:10.1038/322811a0, 1986.

Walker, J. C. and Dudhia, A.: Measurement from sun-synchronous orbit of a reaction rate controlling the diurnal $\mathrm{NO}_{\mathrm{x}}$ cycle in the stratosphere, Atmos. Chem. Phys., 11, 4861-4872, doi:10.5194/acp-11-4861-2011, 2011.

Wofsy, S. C., McElroy, M. B., and Young, Y. L.: The chemistry of atmospheric bromine, J. Geophys. Res., 2, 215-218, doi:10.1029/GL002i006p00215, 1975. 